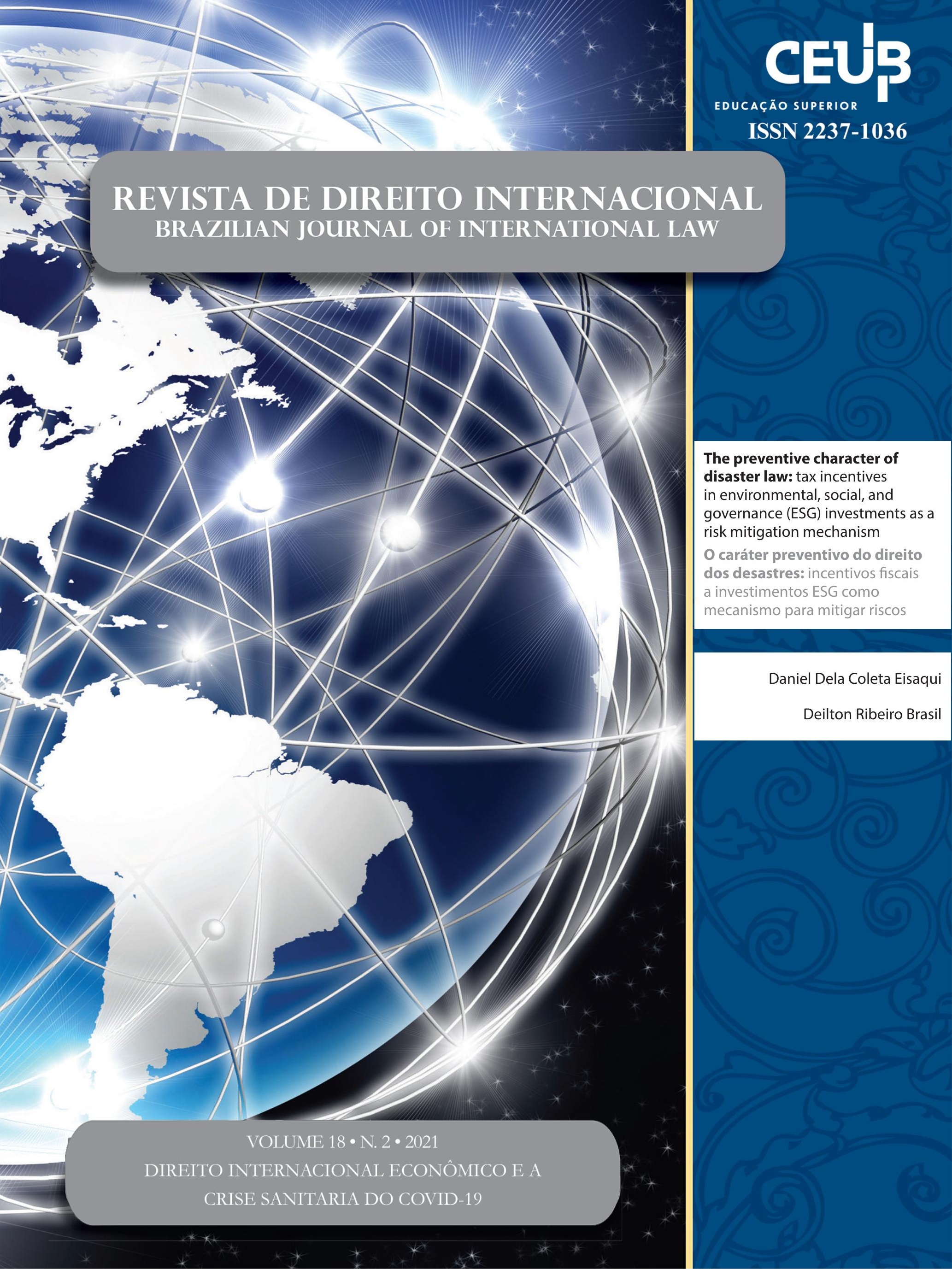




\section{Sumário}

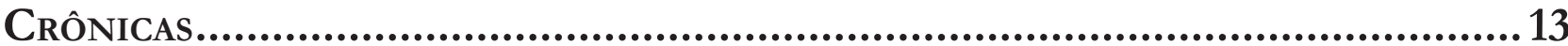

REIMAgining INTERNATIONAL RELATIONS TEACHING DURING (AND AFTER) COVID-19 ........15 Magdalena Bas

Dossiê Temático: Direito Internacional Econômico e a Crise sanitaria Do COVID-19 (INTERNATIONAL ECONOMic LaW AND THE COVID-19 SANITARY CRISIS) 19

Some QUESTIONS ABOUt INTERNATIONAL ECONOMic LAW RAISED DURING THE PANDEMIC .....21 Hervé Ascensio

International Economic LaW and the COVID-19 Sanitary Crisis: An Introduction 27 Julien Chaisse

TransparênCIA E COOPERAÇão REgUlatóRIA No COMÉRCIO INTERNACIONAL DE PRODUTOS MÉDicos PaRa a COVID-19: uMa ANÁlISE da ATUAÇão INSTITUCIONAL DA OMC E DAS NOTIFICAÇõES do Brasil EM OBSERVÂNCIA AOS ACordos TBT E SPS .35

Magali Favaretto Prieto Fernandes e Michelle Ratton Sanchez Badin

O DEVER HUMANO DE PROMOÇÃo DA SAÚDE: A AVIAÇÃo COMERCIAL INTERNACIONAL EM PERÍODOS DE CALAMIDADE SANITÁRIA E DO RETORNO À NORMALIDADE .56

Thiago de Oliveira Frizera, Luisa Cortat Simonetti Gonçalves e Adriano Sant'Ana Pedra

Police Powers Doctrine: a reliable State Defense in times of Covid-19?.... .73 Thomas Lehmann

A inexistênCia do Controle preventivo legislativo de Convencionalidade da Medida Provisória n. ${ }^{\circ} 936 / 2020$ .91

Danilo Garnica Simini, Gabriel Carvalho Moreira e Rafaela Souza Machado 
A Critical analysis of the implications of Covid-19 on piracy off the Nigerian COAST

Kalu Kingsley Anele

The COVID-19 PANDEMIC AS AN IMPELlER FOR THE AGgRAVATION OF MARINE PLASTIC POLLUTION AND ECONOMIC CRISIS: THE REVERSE EFFECT OF HEALTH PROTECTION MEASURES ON HUMAN LIVES 135

Adriana Isabelle Barbosa Lima Sá Leitão e Tarin Cristino Frota Mont’Alverne

Artigos sobre outros temas

O Direito Internacional Humanitário nos Pareceres Consultivos da Corte Internacional de Justiça: uma Conjugação de Perspectivas Utópicas e Apologéticas 156

Talis Prado Pinto Junior e Arthur Roberto Capella Giannattasio

Contesting immunities in the International Criminal Court: an analysis of the RUlings of the Pre-Trial Chambers and the Appeals Chamber in Al Bashir Case and its OUTCOMES. 171

Luisa Giannini e Roberto Vilchez Yamato

Rumo à Profissionalização da Prevenção de Controvérsias nos Acordos de CooperaÇão e Facilitação de InVEstimentos (ACFIs) do Brasil? 191

Nitish Monebhurrun e Leonardo Vieira Arruda Achtschin

THE PREVENTIVE CHARACTER OF DISASTER LAW: TAX INCENTIVES IN ENVIRONMENTAL, SOCIAL, AND GOVERNANCE (ESG) INVESTMENTS AS A RISK MITIGATION MECHANISM 212

Daniel Dela Coleta Eisaqui e Deilton Ribeiro Brasil

A URGÊNCIA DE UM MODELO DE GOVERNANÇA INTERNACIONAL DA ÁGUA: ELEMENTOS PARA A DISCUSSÃO

José Irivaldo Alves Oliveira Silva

O FIM DA HIERARQUIA SUPRALEgAL DOS TRATADOS INTERNACIONAIS: ANÁLISE DA ADI N.O 5.543/2020-DF: À luZ dA TeOria ARgumentativa de Neil Maccormick. 
Os DIREITOS HUMANOS FRENTE À NORMATIVIDADE “IMPERIAL" E A RESPONSABILIDADE DAS EMPRESAS TRANSNACIONAIS POR VIOLAÇÃO AOS DIREITOS HUMANOS NA ERA DO “IMPÉRIO” 280

Fernando Hoffmam e Jose Luis Bolzan de Morais

O RECONHECIMENTO FACIAL NAS SMART CITIES E A GARANTIA DOS DIREITOS À PRIVACIDADE E À PROTEÇÃO DE DADOS PESSOAIS.. 302

Diogo Dal Magro e Vinícius Borges Fortes

O DESENVOLVIMENTO HISTÓRICO DA PROSCRIÇÃo DO DESAPARECIMENTO FORÇADO DE PESSOAS E sua fenomenologia no Direito Penal Internacional e no Direito Internacional dos Direitos Humanos

Marcus Vinícius Xavier de Oliveira

CONSTITUCIONALISMO COOPERATIVO GLOBAL E DIREITO INTERNACIONAL PRIVADO: INSTRUMENTOS PARA UMA GOVERNANÇA DE DIREITO TRANSNACIONAL NA INTEGRAÇÃO. 362

Anderson Vichinkeski Teixeira, Roberto Correia da Silva Gomes Caldas e Luciane Klein Vieira

Proteção da inovação pela aplicaÇão do Direito da ConcorrênCia da União Europeia: ANÁLISE DA INDÚSTRIA FARMACÊUTICA.

Pablo Leurquin 


\title{
The preventive character of disaster law: tax incentives in environmental, social, and governance (ESG) investments as a risk mitigation mechanism*
}

\author{
O caráter preventivo do direito dos \\ desastres: incentivos fiscais a investimentos \\ ESG como mecanismo para mitigar riscos
}

\author{
Daniel Dela Coleta Eisaqui** \\ Deilton Ribeiro Brasil ${ }^{* * *}$
}

\begin{abstract}
This article analyses the possibility of using tax incentives in environmental, social, and governance (ESG) investments to help prevent disasters. It elucidates whether tax incentives are a useful disaster prevention mechanism and how and what type of tax incentives can be used. Its focus is dogmatic and the method of approach is deductive. The research method is both bibliographic and documental, using doctrine, national legislation, and international treaties. The findings reveal that it is possible to prevent disasters with tax incentives in ESG investments if the economic agents act in accordance with the notion of benefits; moreover, environmentally responsible conduct can be undertaken if it is less costly.
\end{abstract}

Keywords: Disaster law. Taxation. ESG investments. Environmental law. Sustainable development.

* Recebido em 30/03/2021

Aprovado em 13/05/2021

** Doutorando em Proteção dos Direitos Fundamentais na Universidade de Itaúna (UIT). Mestre em Direitos Difusos e Coletivos pela Universidade Metodista de Piracicaba (UNIMEP). Bacharel em Ciências Jurídicas pela Universidade Metodista de Piracicaba (UNIMEP).

Advogado

Email: danicoleta@hotmail.com

*** Pós-doutor em Direito pela UNIME, Itália. Doutor em Direito pela UGF/RJ. Professor da Graduação e do PPGD da Universidade de Itaúna (UIT), Faculdades Santo Agostinho (FASASETE-AFYA) e Faculdade de Direito de Conselheiro Lafaiete (FDCL). Professor visitante da Universidade de Caxias do Sul (UCS). Email: deilton.ribeiro@terra.com.br

\section{Resumo}

Este artigo analisa a possibilidade de se utilizar incentivos fiscais a investimentos ESG na intenção de prevenir desastres. Seu objetivo é compreender se incentivos fiscais são um mecanismo útil de prevenção de desastres, e como e quais incentivos fiscais podem ser utilizados. O foco é dogmático e o método de abordagem é dedutivo. A pesquisa é bibliográfica e documental, utilizando doutrina, legislação nacional e tratados internacionais. Como resultado, o artigo conclui que é possível prevenir desastres com incentivos fiscais para investimentos ESG na medida em que agentes econômicos agem de acordo com a noção de benefícios e podem escolher condutas socialmente responsáveis se elas forem menos custosas.

Palavras-chave: Direito dos desastres. Tributação. Investimentos ESG. Direito ambiental. Desenvolvimento sustentável. 


\section{Introduction}

This article analyses the possibility of using tax incentives in environmental, social, and governance (ESG) investments to prevent disasters. ESG investments are a new approach in the financial market including ethical issues in investment decisions' logical operations, that is, non-financial assumptions are added to the syllogism by which investors decide how to allocate their resources. In this sense, the quest for maximum profit is no more the only concern, instead investors also take into account the social and environmental impacts of their assets.

Additionally, disaster prevention implies both public and private actions and joint efforts through infrastructure works and positive social and environmental behaviors. Consequently, the state plays an important role to promote an environment conducive for encouraging private actors contribute to disaster prevention, environmental conservation, social justice, and general welfare.

The problem under discussion is whether the use of tax incentives in ESG investments contributes to disaster prevention; in other words, whether this tax policy can generate environmentally responsible behaviors. In this vein, there are two objectives: a) understanding whether tax incentives are a useful disaster prevention mechanism; and b) how and what type of tax incentives are useful to this end. The main hypothesis is that tax incentives induce economic agents to seek environmentally and socially responsible investments if they become more attractive.

This subject is justified on the grounds of current reality. First, the occurrence of disasters, man-made or natural, has become more frequent; even while this article is being written, mankind is facing the second year of a globally deadly epidemic. Second, the financial market has seen an increase in social and environmental interest in responsible investments. For example, there is an increase in available investment options that are related to non-financial issues, with various events being organized to discuss these concerns.

Methodologically, this article is a qualitative research with a dogmatic focus, that is, it seeks legal responses to the challenges of disaster prevention through the financial market and economic theory. By the same reason, this investigation is also classified as an applied research.
The method of approach is deductive, which is the process of reasoning from one or more statements (premises) to reach a logical conclusion: If disaster law has a preventive nature and economic agents act in response of incentives and desincentives, then tax incentives may be able to induce precautionary measures, preventing disasters. In this vein, it is an exploratory research. The research method is bibliographic, which is based in the light of doctrines, and also is documentary, because it uses legal norms, both national legislation and international treaties.

This article is divided into six sections, including the introduction. Chapter 1 explains what disaster law is and its importance in current society. Chapter 2 presents an analysis of dimensions of development and the symbiotic relationships between sustainability and governance. Chapter 3 is an overwiew of the emergence of eco-capitalism, the green economy, and ESG investments. Chapter 4 is dedicated to the possibility of using tax incentives in ESG investments as risk management and mitigation solution. The final section presents the main conclusions.

\section{Disaster law as an imperative in risk society}

Disasters are phenomena caused by natural events, human intervention, or both, that result in significant costs, damages, and losses, both environmental and social, including harmful environmental changes, detriment to human interests, and substantial loss of human lives and goods. ${ }^{1}$

At a conceptual level, according to the applicable Brazilian law (Decree n. 10.593, of December 24, 2020), a "disaster" is the result of an adverse event, man-made or natural, that causes human, material, and environmental damages and social and economic losses, as defined in Article 2 (VII) of the aforementioned Decree. ${ }^{2}$

The state's purpose is —or, at least, should be-the common good: the role of law and its institutions is to

CARVALHO, Délton Winter de; DAMACENA, Fernanda Dalla Libera. Direito dos desastres. Porto Alegre: Livraria do Advogado, 2013. p. 27-29.

2 BRASIL. Decree n. 10.593, of December 24, 2020. Available at: http://www.planalto.gov.br/ccivil_03/_Ato2019-2022/2020/Decreto/D10593.htm\#art42. Accessed: 06 Mar. 2021. 
act on behalf of the general welfare. ${ }^{3}$ In other words, "the State, as a juridical-political entity, has as its general purpose the common good of its people, that is, ensuring the contiditions that collaborate to the integral development of human personality."4

In this sense, there is a need for a theoretical formulation of a legal framework for environmental and social safety standards, covering risk assessment and mitigation processes (preventive approach), along with emergency responses, reconstrucion of areas affected, rehabilitation of displaced people, and compensation, ${ }^{5}$ without forgetting civil and criminal liability. This necessary legal framework is understood under the rubric of "disaster law."

\subsection{Law as a tool for preventive risk management}

In his book "The Age of Rights," Norberto Bobbio states that rights are a signum prognosticum, a signal of the times, arising from specific conditions: the rights "come into existence, when their existence is either essential or possible," when progress "creates new threats [...] or allows new remedies." He believes that "specific demands are created in response to specific needs. New needs are created by chances in social conditions, and when technical developments make it possible to satisfy them."7

The division of rights into generations is illustrative of this historical approach. As Mark Tushnet points out, the "first generation rights emerged as bourgeois society and markets displaced feudal relations" and the "second generation rights resulted from a later political

3 DWORKIN, Ronald. Levando os direitos a sério. São Paulo: WMF Martins Fontes, 2020. p. VIII.

4 KIM, Richard Pae; EISAQUI, Daniel Dela Coleta. "Máximo existencial possível" no sopesamento entre o direito fundamental à educação superior e o interesse público ao equilíbrio fiscal. In: COSTA, Daniel Castro Gomes da; FONSECA, Reynaldo Soares da; BANHOS, Sérgio Silveira; CARVALHO NETO, Tarcísio Vieira de (coord.). Democracia, justiça e cidadania: desafios e perspectivashomenagem ao Ministro Luís Roberto Barroso. Tomo II: Pensando as instituições, a justiça e o Direito. Belo Horizonte: Fórum, 2020. p. 176.

5 CARVAlHO, Délton Winter de; DAMACENA, Fernanda Dalla Libera. Direito dos desastres. Porto Alegre: Livraria do Advogado, 2013. p. 30.

6 BOBBIO, Norberto. A era dos direitos. Rio de Janeiro: Elsevier, 2004. p. 9.

BOBBIO, Norberto. A era dos direitos. Rio de Janeiro: Elsevier, 2004. p. 10. mobilization, of the working class in Europe, expressed in social democratic parties of the late nineteenth century." 8

According to Bobbio, the increasing power of one man over another, technical progress, and the increases in man's ability to dominate nature ${ }^{9}$ have caused the recognition and proclamation of a third generation of rights associated with environmental movements and a better social governance paradigm, focusing on the human dimension.

It is possible to define "law" as a mechanism of social control, but it is also a path "to reinforce the demands by movements on behalf of themselves and others for the satisfaction of new material and moral needs." ${ }^{10}$ Both considerations are correlated because law provides directive principles of public policies, regulation, control over behaviors, and conduct standards directed toward the protection of human interests. Moreover, a healthy quality of life, ecologically balanced environment, security, well-being, and development are rights and are enforceable_-including on account of international obligations. ${ }^{11}$

In this vein, the notion of risk becomes important. There is no way to protect all these rights without preventive action and risk management. Ultimately, effective protection of human rights reduces human vulnerability. Furthermore, when this is the subject on the agenda, it is necessary to comprehend the risk issue.

The now classic work by Ulrich Beck, "Risk society: towards a new modernity", proposes as its core thesis the increasing distribution of social risk positions, which requires "a systematic way of dealing with hazards and insecurities." ${ }^{\prime 2} \mathrm{He}$ further states, "risk society" is

8 TUSHNET, Mark. Notes on some aspects of the taxonomy of "generations" of rights: a dossier on taxonomy of generation of rights. Revista estudos institucionais, v. 2, n. 2, 2016. Available at: https:// www.estudosinstitucionais.com/REI/article/download/77/94. Accessed: 27 Feb. 2021. p. 476.

9 BOBBIO, Norberto. A era dos direitos. Rio de Janeiro: Elsevier, 2004. p. 9.

${ }_{10}$ BOBBIO, Norberto. A era dos direitos. Rio de Janeiro: Elsevier, 2004. p. 11.

11 ANTONIAZZI, Mariela Morales; PIOVESAN, Flávia; IGNÁCIO, Renata Rossi.Covid-19 e direitos econômicos, sociais, culturais e ambientais (DESCA): impacto dos estandares interamericanos. Revista de direito econômico e socioambiental, Curitiba, v. 11, n. 1, p. 5990, jan./abr. 2020. Available at: https://periodicos.pucpr.br/index. $\mathrm{php} /$ direitoeconomico/article/download/27353/24621. Accessed: 03 Mar. 2021. p. 66.

12 BECK, Ulrich. Risk society: towards a new modernity. London: 
one "that it is increasingly occupied with debating, preventing and managing risks that it itself has produced." 13

Beck's definitions allow the conclusion that a "risk society" is a society governed by the possibility of its own destruction due to negative and undesirable consequences of natural events and human activity. In accordance with Slavoj Žižek, ${ }^{14}$ " "nature is no longer 'natural', the reliable 'dense' background of our lives; it now appears as a fragile mechanism which, at any point, can explode in a catastrophic manner." He also writes: "the predominant version of ecology is the ecology of fear, fear of a catastrophe-human-made or natural - that may deeply perturb, destroy even, human civilization." 15

Considering law as a mechanism of social control and the historical nature of rights, the incidence-or even the mere possibility_ of environmental disasters act as a trigger for law and politics to develop new regulatory and legal frameworks, based on the intention to prevent environmental damages, social harm, and other destructive events. ${ }^{16}$ In the words of Žižek, the abovementioned fear "pushes us to plan measures to protect our safety."

On the one hand, new rights are recognized, while on the other new fields of law emerge. In this context, a new field of research has emerged and is under development, focusing on "a wide-ranging, interdisciplinary body of research seeking to inform and improve disaster-related decision-making"17: Disaster Law. By definition, the study object in this area of law is "a complex web of obligations, duties and interests related to prevention and catastrophic events assistance", with the intention of managing the "havoc of disasters." 18

SAGE Publications, 1992, p. 21.

13 BECK, Ulrich. Living in the world risk society. Economy and Society, v. 35, n. 3, p. 329-345, aug. 2006. Available at: https://edisciplinas.usp.br/pluginfile.php/4095470/mod_resource/content/0/ Beck--WorldRisk.pdf. Accessed: 05 Mar. 2021. p. 332.

14 ŽIŽEK, Slavoj. In defense of lost causes. London, New York: Verso, 2008. p. 435.

15 ŽIŽEK, Slavoj. In defense of lost causes. London, New York: Verso, 2008. p. 438.

16 CARVALHO, Délton Winter de; DAMACENA, Fernanda Dalla Libera. Direito dos desastres. Porto Alegre: Livraria do Advogado, 2013. p. 16-17.

17 FARBER, Daniel. Disaster law and emerging issues in Brazil. Revista de Estudos Constitucionais, Hermenêutica e Teoria do Direito (RECHTD), v. 4, n. 1, 2012. Available at: http://www.revistas.unisinos. br/index.php/RECHTD/article/view/rechtd.2012.41.01/932. Accessed: 04 Mar. 2021. p. 4.

18 CARVALHO, Délton Winter de; DAMACENA, Fernanda Dalla Libera. Direito dos desastres. Porto Alegre: Livraria do Advogado,
The main guidelines of disaster law are the preventive and precautionary principles: events such as natural or environmental disasters have an irreversible impact on human lives and local ecosystems, and also adversely impact future generations. Therefore, "either we take this threat seriously and decide today to do things which, if the catastrophe does not occur, will appear ridiculous, or we do nothing and lose everything in the case of a catastrophe, the worst choice being that of a middle position, taking a limited number of measures-in which case, we fail whatever should happen." 19 Seen in these terms, the raison d'etre of this new branch of law is to formulate preventive strategies grounded on risk management and the reduction of vulnerabilities. ${ }^{20}$

\subsection{International nature of disaster law}

Klaus Bosselmann ${ }^{21}$ states that the current resource crisis is global, implying that an overall strategic approach is needed: There is no longer any room for local sustainablity strategies. Indeed, again citing Žižek, ${ }^{22}$ "the only way to confront the threat of ecological catastrophe is by means of large-scale collective decisions," suggesting the imposition of the same world-wide norms, or at least the same regulatory rationality: anticipation, precaution, and risk control.

This rationality, the Slovenian philosopher says, recognizes that "the only truly effective one in the face of a calamity" is, "instead of saying 'the future is still open, we still have the time to act and prevent the worst', one should accept the catastrophe as inevitable, and then act to retroactively undo what is already 'written in the stars' as our destiny." 23

Daniel Farber ${ }^{24}$ incorporates a more economic approach, saying, in line with Žižek, that "an economic

2013. p. 67.

19 ŽIŽEK, Slavoj. In defense of lost causes. London, New York: Verso, 2008. p. 456.

20 CARVALHO, Délton Winter de; DAMACENA, Fernanda Dalla Libera. Direito dos desastres. Porto Alegre: Livraria do Advogado, 2013. p. $17-18$.

21 BOSSELMANN, Klaus. O princípio da sustentabilidade: transformando direito e governança. São Paulo: Revista dos Tribunais, 2015. p. 42.

22 ŽIŽEK, Slavoj. In defense of lost causes. London, New York: Verso, 2008. p. 461.

23 ŽIŽEK, Slavoj. In defense of lost causes. London, New York: Verso, 2008. p. 460.

24 FARBER, Daniel. From here to eternity: environmental law and future generations. University of Illinois Law Review, n. 2, 2003. Avail- 
technique called exponential discounting converts future benefits into their equivalent present-days values." ${ }^{25}$ Nevertheless, both ideas are linked, as they consider the need of looking toward the future and redesigning the present: "whatever actions we take today, however, will have most of their effects far in the future."26

As stated, crisis management and disaster prevention demand international efforts. ${ }^{27}$ There is a collective international responsibility to protect and ensure human security: safety from chronic threats and "from sudden and hurtful disruptions in the patterns of daily life", covering, e.g., economy, food, health, environment, physical integrity, culture, and "first generation" fundamental rights. ${ }^{28}$

Therefore, in addition to its preventive nature, disaster law also has an international dimension. ${ }^{29}$ Carvalho and Damacena ${ }^{30}$ refer to the World Conference on Disaster Reduction (2005, in Japan), an international event wherein the Hyogo Framework for Action 2005-2015 was adopted, whereby "efforts to reduce disaster risks must be systematically integrated into policies, plans and programs for sustainable development and poverty reduction and supported through bilateral, regional and international cooperation." ${ }^{31}$

able at: https://illinoislawreview.org/print/volume-2003-issue-2/ from-here-to-eternity-environmental-law-and-future-generations/. Accessed: 20 Mar. 2021. p. 291.

25 FARBER, Daniel. From here to eternity: environmental law and future generations. University of Illinois Law Review, n. 2, 2003. Available at: https://illinoislawreview.org/print/volume-2003-issue-2/ from-here-to-eternity-environmental-law-and-future-generations/. Accessed: 20 Mar. 2021. p. 293.

26 FARBER, Daniel. From here to eternity: environmental law and future generations. University of Illinois Law Review, n. 2, 2003. Available at: https://illinoislawreview.org/print/volume-2003-issue-2/ from-here-to-eternity-environmental-law-and-future-generations/. Accessed: 20 Mar. 2021. p. 290.

27 CARVALHO, Délton Winter de; DAMACENA, Fernanda Dalla Libera. Direito dos desastres. Porto Alegre: Livraria do Advogado, 2013. p. 112-117.

28 PARIS, Roland. Human security: paradigma shift or hot air? International Security, v. 26, n. 2, p. 87-102, 2001. Available at: http://users.metu.edu.tr/utuba/Paris.pdf. Accessed: 05 Mar. 2021. p. 89-91.

29 Cf. CARVALHO, Délton Winter de. Desastres ambientais e sua regulação jurídica: deveres de prevenção, resposta e compensação ambiental. 2. ed. São Paulo: Revista dos Tribunais, 2020. p. 66 et. seq.

30 CARVALHO, Délton Winter de; DAMACENA, Fernanda Dalla Libera. Direito dos desastres. Porto Alegre: Livraria do Advogado, 2013. p. 58.

31 UNITED NATIONS. Report of the World Conference on Disaster Reduction. 2005. Available at: https://undocs.org/en/A/CONF.206/6. Accessed: 07 Mar. 2021. p. 7.
First, because "causes and consequences of disasters are not limited to one geographical location or space," disasters and catastrophes "are in principle omnipresent." ${ }^{32}$ This leads to the need for the international community to consider both protecting and improving the environment and ensuring sustainability from transnational threats; for example, the Convention on the protection of the Mediterranean Sea against pollution (Barcelona Convention, 1976), which recognizes "the need for close cooperation among the States and international organizations concerned in a coordinated and comprehensive regional approach for the protection and enhancement of the marine environment." ${ }^{33}$

Second, for some authors, the very definition of "disaster" concerns the occurrence of "emergency situations in which there is an urgent need for international assistance to relieve human suffering." 34 A similar definition is provided by the Center for Research on the Epidemiology of Disasters (CRED): "situation or event, which overwhelms local capacity, necessitating a request to national or international level for external assistance." $35^{35}$

Even if the disaster is in fact local, the disaster law system is international for the following reasons:

a) the understanding of environment and natural resources as a common heritage of mankind, existing for the benefit of mankind as a whole, and the recognition of human security and sustainable development as fundamental rights of all individuals. As pointed out by the Paris Agreement (2015), once the environment is considered an asset of human common use, there is also a common concern of humankind on environmental threats. $^{36}$

32 BECK, Ulrich. Living in the world risk society. Economy and Society, v. 35, n. 3, p. 329-345, aug. 2006. Available at: https://edisciplinas.usp.br/pluginfile.php/4095470/mod_resource/content/0/ Beck--WorldRisk.pdf. Accessed: 05 Mar. 2021. p. 333.

33 UNITED NATIONS. Treaty series: treaties and international agreements registered or filed and recorded with the Secretariat of the United Nations, v. 1102. New York: United Nations, 1991. Available at: https://treaties.un.org/doc/Publication/UNTS/Volume\%201102/v1102.pdf. Accessed: 06 Mar. 2021. p. 45.

34 MACALISTER-SMITH, Peter. International humanitarian assistance: disaster relief actions in international law and organization. Dordrecht: Martinus Nijhoff Publishers, 1985. p. 3.

35 CENTRE FOR RESEARCH ON THE EPIDEMIOLOGY OF DISASTERS (CRED). EM-DAT Glossary. Available at: https:// www.emdat.be/Glossary\#letter_d. Accessed: 06 Mar. 2021.

36 UNITED NATIONS. Paris Agreement. 2015. Available at: https://unfccc.int/sites/default/files/english_paris_agreement.pdf. 
b) the potential need for international humanitarian aid. It was this spirit that guided the Convention on assistance in the case of a nuclear accident or radiological emergency (1986), which encouraged international cooperation "to facilitate prompt assistance in the event of a nuclear accident or radiological emergency." ${ }^{37}$ In the same way, the Framework Convention on Civil Defense Assistance (2000) was guided by "the need for the development of international cooperation in the field of Civil Defense in terms of prevention, forecasting, preparedness, intervention, and post-crisis management." ${ }^{38}$

c) the fact that environmental damage recognizes no borders, as was the case of the April 1986 disaster at the Chernobyl nuclear power plant in Ukraine, whose effects were felt in Sweden, because the radioactive material released from the Soviet nuclear power plant was carried by the wind and spread over Europe and other areas in the world. ${ }^{39}$ This fact was recognized by the Framework Convention on Civil Defense Assistance (2000): "the risk of disasters and the consequences thereof are not containable by national frontiers." "40 In truth, as pointed out by Bosselmann, ${ }^{41}$ everything that is done at a local level has repercussions in other parts of the world-something like the butterfly effect in chaos theory.

Accessed: 07 Mar. 2021. p. 2.

37 UNITED NATIONS. Treaty series: treaties and international agreements registered or filed and recorded with the Secretariat of the United Nations, v. 1457. New York: United Nations, 1997. Available at: https://treaties.un.org/doc/Publication/UNTS/Volume\%201457/v1457.pdf. Accessed: 07 Mar. 2021. p. 134.

38 UNITED NATIONS. Treaty series: treaties and international agreements registered or filed and recorded with the Secretariat of the United Nations, v. 2172. New York: United Nations, 2004. Available at: https://treaties.un.org/doc/publication/unts/volume $\% 20$ 2172/v2172.pdf. Accessed: 07 Mar. 2021. p. 231.

39 Cf. HÄGG, Conny. Consequences in Sweden of the Chernobyl accident. Stockholm: National Institute of Radiation Protection, 1990. Available at: https://inis.iaea.org/collection/NCLCollectionStore/_Public/21/071/21071159.pdf?r=1\&r=1. Accessed: Mar. 06, 2021; EUROPEAN PARLIAMENT. Forsmark: how Sweden alerted the world about the danger of the Chernobyl disaster. May 15, 2014. Available at: https://www.europarl.europa.eu/news/en/headlines/ society/20140514STO47018/forsmark-how-sweden-alerted-theworld-about-the-danger-of-chernobyl-disaster. Accessed: 06 Mar. 2021.

40 UNITED NATIONS. Treaty series: treaties and international agreements registered or filed and recorded with the Secretariat of the United Nations, v. 2172. New York: United Nations, 2004. Available at: https://treaties.un.org/doc/publication/unts/volume $\% 20$ 2172/v2172.pdf. Accessed: 07 Mar. 2021. p. 231.

${ }^{41}$ BOSSELMANN, Klaus. O princípio da sustentabilidade: transformando direito e governança. São Paulo: Revista dos Tribunais, 2015. p. 42. d) the very existence of international conventions imposes duties and obligations in environmental matters. ${ }^{42}$ As Álisson Thiago de Assis Campos and Deilton Ribeiro Brasil ${ }^{43}$ have argued, there are international standards for human protection requiring the proactive stance of states in order to promote effective global action to protect human rights. Within this article's scope, these standards do not remain in the environmental law field, but also concern investment law. ${ }^{44}$ In this sense, "scientific environmental studies measure the environmental impacts of an investment" and there is the investor's duty of due diligence "to assess the environmental nature of the investment site" and "examine the environmental impacts of his activities." 45

The internationalization of disaster law involves a whole set of treaties - in a broad sense- directly or indirectly related to disaster prevention, post facto responses, environmental protection and sustainable development. ${ }^{46}$ In this respect, there is an effort by the

${ }_{42}$ MACHADO, Paulo Affonso Leme. Direito à informação e meio ambiente. 2. ed. São Paulo: Malheiros, 2018. p. 111-182; CARVALHO, Délton Winter de. Desastres ambientais e sua regulação jurídica: deveres de prevenção, resposta e compensação ambiental. 2. ed. São Paulo: Revista dos Tribunais, 2020. p. 66-69.

43 CAMPOS, Alísson Thiago de Assis; BRASIL, Deilton Ribeiro. A internacionalização dos direitos humanos e a retomada das práticas restaurativas no processo penal. Rev. de Formas Consensuais de Solução de Conflitos, v. 3, n. 2, p. 01-18, Jul./Dez. 2017. e-ISSN: 2525-9679. Available at: https://www.indexlaw.org/index.php/revistasolucoesconflitos/article/view/2225/pdf. Accessed: 07 Mar. 2021. p. 10.

${ }^{44}$ MONEBHURRUN, Nitish. Is investment arbitration an appropriate venue for environmental issues? A Latin American perspective. Revista de Direito Internacional, Brasília, v. 10, n. 1, p. 195-206, 2013. Available: https://www.publicacoesacademicas.uniceub.br/ rdi/article/view/2070/pdf. Accessed: 09 May 2021. p. 197.

45 MONEBHURRUN, Nitish. Is investment arbitration an appropriate venue for environmental issues? A Latin American perspective. Revista de Direito Internacional, Brasília, v. 10, n. 1, p. 195-206, 2013. Available: https://www.publicacoesacademicas.uniceub.br/ rdi/article/view/2070/pdf. Accessed: 09 May 2021. p. 202-204.

46 Cf. FISCHER, Horst. International disaster response law treaties: trends, patterns and lacunae. In: INTERNATIONAL FEDERATION OF RED CROSS AND RED CRESCENT SOCIETIES. International disaster response laws, principles and practice: reflections, prospects and challenges. Geneva: 2003. Available at: https://www.ifrc. org/PageFiles/41194/idrl-book-c2.pdf. Accessed: 07 Mar. 2021; INTERNATIONAL FEDERATION OF RED CROSS AND RED CRESCENT SOCIETIES. Law and legal issues in international disaster response: a desk study. Geneva: International Federation of Red Cross and Red Crescent Societies, 2007. Available at: https:// www.ifrc.org/PageFiles/125712/113600-idrl-deskstudy-en.pdf. Accessed: 07 Mar. 2021. Also, the International Federation of Red Cross and Red Crescent Societies provide a data base of legal and policy instruments related to disaster management at the international, regional, national, provincial, and local levels, available at: 
International Federation of Red Cross and Red Crescent Societies to systematize a global regulatory logic through a set of recommendations on disaster relief operations and humanitarian assistance. ${ }^{47}$

For example, Principle 15 of the Rio Declaration on Environment and Development, proclaimed in the United Nations Conference on Environment and Development (Rio de Janeiro, 1992), provides that, "in order to protect the environment, the precautionary approach shall be widely applied by States according to their capabilities." ${ }^{48}$ Another example is the Tampere Convention on the Provision of Telecommunication Resources for Disaster Mitigation and Relief Operations (Tampere, 1998), which stated the need for international cooperation "to facilitate the use of telecommunication resources for disaster mitigation and relief." 49

In fact, the epistemological basis of disaster law is the interaction between the right to an ecologically balanced environment and to a healthy quality of life, from the perspective of intergenerational responsibility, human security, and sustainable development. This article further elucidates that the development concept is no longer just about economic growth.

\section{The dimensions of development and the symbiotic relationships between sustainability and governance}

There is a positive connotation inherent to the concepts of progress and development. Economic growth, increasing productive capacity, positive employment indicators, and favorable stock market developments are examples of the traditional concept of progress and

https://www.ifrc.org/en/publications-and-reports/idrl-database/.

47 Available at: https://www.ifrc.org/en/what-we-do/disaster-law/ about-disaster-law/international-disaster-response-laws-rules-andprinciples/.

48 UNITED NATIONS. Report of the United Nations Conference on Environment and Development. 1992. Available at: https://www.un.org/ en/development/desa/population/migration/generalassembly/ docs/globalcompact/A_CONF.151_26_V.I_Declaration.pdf. Accessed: 06 Mar. 2021. p. 3.

49 UNITED NATIONS. Treaty series: treaties and international agreements registered or filed and recorded with the Secretariat of the United Nations, v. 2296. New York: United Nations, 2006. Available at: https://treaties.un.org/doc/Publication/UNTS/Volume\%202296/v2296.pdf. Accessed: 07 Mar. 2021. p. 47. development. However, this financial and economic growth is not always accompanied by human, social, and environmental development.

New methods of thought emerged when these concerns were introduced in the notion of development. Amartya Sen, the Nobel Laureate in Economics in 1998, argued in his book Development as Freedom that development is not simply a matter of metrics such as gross domestic product, industrialization, technological advance, or income per capita; rather, it is about providing freedom and conditions that enable the people to exercise this freedom.

In his words, "development requires the removal of major sources of unfreedom: poverty as well as tyranny, poor economic opportunities as well as systematic social deprivation, neglect of public facilities as well as intolerance or overactivity of repressive states." ${ }^{\circ 0} \mathrm{He}$ points out: "sometimes the lack of substantive freedoms relates directly to economic poverty," while in other cases it "links closely to the lack of public facilities and social care," and, in still other cases, it "results directly from a denial of political and civil liberties [...] and from imposed restrictions on the freedom to participate in the social, political and economic life of the community." 51

Thus, development is about "economic opportunities, political libertities, social powers, and the enabling conditions of good health, basic education, and the encouragement and cultivation of initiatives." ${ }^{\prime 2}$ This article does not provide an in-depth analysis of Amartya Sen's thought, but touches on it to introduce the multidimensional nature of development.

First, there is a social dimension: A model of socially exclusionary and unequal development is not acceptable. ${ }^{53}$ Second, the new paradigm of development seeks an ethical approach: empathy, solidarity, cooperation, avoidance of cruelty, not turning human beings into a thing or commodity, recognizing all of them as the masters of their own fates (Kantian autonomy), honesty of purpose, fairness, and the improvemnt of collective and

\footnotetext{
50 SEN, Amartya. Desenvolvimento como liberdade. São Paulo: Companhia das Letras, 2010. p. 16-17.

51 SEN, Amartya. Desenvolvimento como liberdade. São Paulo: Companhia das Letras, 2010. p. 17.

52 SEN, Amartya. Desenvolvimento como liberdade. São Paulo: Companhia das Letras, 2010. p. 18.

53 FREITAS, Juarez. Sustentabilidade: direito ao futuro. 4. ed. Belo Horizonte: Fórum, 2019. p. 65.
} 
individual wellbeing. ${ }^{54}$ Third, there is the most common and known dimension, i.e., the economic one. ${ }^{55}$ Fourth is the political-legal dimension, covering a matrix of fundamental rights and social duties, in order to provide a new type of development. ${ }^{56}$

Finally, there is the environmental dimension. ${ }^{57}$ In acordance with Bosselmann, ecological sustainability is a prerequisite for development. For him, the true meaning of sustainability is the duty to protect and restore the integrity of the Earth's ecological systems. Therefore, economic prosperity and social justice are subject to ecological sustainability. ${ }^{58}$

In line with this argument, it is possible to conclude that sustainability and governance are two sides of the same coin, and therefore they maintain a symbiotic relationship with each other. If sustainability is the duty to protect and restore the integrity of the Earth's ecological systems, as understood by Bosselmann, the consequence is that it becomes necessary to form rules and decision-making procedures — governance—guided by sustainability. ${ }^{59}$

Governance is not equal to government, namely "all forces that can influence human behavior are potential tools of governance." ${ }^{00}$ For instance, civil society has been widely seen as a crucial agent for improving the quality and inclusiveness of governance. ${ }^{61}$ Hence, it is necessary to have a system of incentives and disincentives that makes social agents act in line with sustainability goals.

54 FREITAS, Juarez. Sustentabilidade: direito ao futuro. 4. ed. Belo Horizonte: Fórum, 2019. p. 68-72.

55 FREITAS, Juarez. Sustentabilidade: direito ao futuro. 4. ed. Belo Horizonte: Fórum, 2019. p. 74-76.

56 FREITAS, Juarez. Sustentabilidade: direito ao futuro. 4. ed. Belo Horizonte: Fórum, 2019. p. 76-82.

57 FREITAS, Juarez. Sustentabilidade: direito ao futuro. 4. ed. Belo Horizonte: Fórum, 2019. p. 72-74.

58 BOSSELMANN, Klaus. O princípio da sustentabilidade: transformando direito e governança. São Paulo: Revista dos Tribunais, 2015. p. 56-78.

59 BOSSELMANN, Klaus; ENGEL, Ron; TAYLOR, Prue. Governance for sustainability: issues, challenges, successes. Gland: International Union for Conservation of Nature and Natural Resources, 2008. p. 4.

60 BOSSELMANN, Klaus; ENGEL, Ron; TAYLOR, Prue. Governance for sustainability: issues, challenges, successes. Gland: International Union for Conservation of Nature and Natural Resources, 2008. p. 4.

61 VELTMEYER, Henry. Civil Society and Local Development. Interações, v. 9, n. 2, p. 229-243, 2008. Available at: http://www.scielo.br/ scielo.php?script $=$ sci_arttext\&pid $=$ S1518-70122008000200010\&ln $\mathrm{g}=$ en\&nrm=iso.Accessed: 11 Mar. 2021. p. 229.
This article focuses on the economic dimension of sustainable governance. Economic factors are an expressive force of influence over the human behavior. As Žižek regrets, capitalism "turn[s] ecology into a new field of capitalist investment." ${ }^{22}$ This logic is not negative in itself: the idea of an Ecological State-an ecosystemic perpespective on the state-necessarily implies a shift in the economic activities. ${ }^{63}$ Therefore, new approaches of capitalism and economy emerge: a "greenification" process.

\section{The emergence of eco-capitalism and green economy: ESG investments as an essential element of sustainable governance}

After the Cold War, Francis Fukuyama declared the end of history. For him, "liberal democracy may constitute the 'end point of mankind's ideological evolution' and the "final form of human government." 64 In this context, "liberal principles in economics - the 'free market'-have spread." ${ }^{65}$ By definition, the Hegelian and Marxist concept of the "end of history" refers to the end point of humanity's sociocultural evolution and the final form of human government, i.e., the total exhaustion of viable systematic alternatives to capitalism and liberal democracies. ${ }^{66}$

However, the environmental demands of current society have contributed to the development of new social, economic, and political structures. In the terminology of Enrique Leff, ${ }^{67}$ there was the emergence

62 ŽIŽEK, Slavoj. In defense of lost causes. London, New York: Verso, 2008. p. 421.

63 CÂMARA, Ana Stela. Economic assumptions of the ecological state: looking for sustainability. Revista de Direito Econômico e Socioambiental, Curitiba, v. 10, n. 3, p. 50-66, set./dez. 2019. Available at: https://periodicos.pucpr.br/index.php/direitoeconomico/article/ download/25687/24226. Accessed: 11 Mar. 2021. p. 64.

${ }^{64}$ FUKUYAMA, Francis. The end of history and the last man. New York: The Free Press, 1992. p. xi.

65 FUKUYAMA, Francis. The end of history and the last man. New York: The Free Press, 1992. p. xiii.

${ }^{66}$ Cf. VIEIRA, Rosa Maria. O fim da historia: de Hegel a Fukuyama. Revista de Administração de Empresas, v. 33, n. 3, 1993. Available at: https://www.fgv.br/rae/artigos/revista-rae-vol-33-num-3-ano1993-nid-47481/. Accessed: 11 Mar. 2021.

${ }^{67}$ Cf. LEFF, Enrique. Sustentabilidad y racionalidad ambiental: hacia 'otro' programa de sociología ambiental. Revista mexicana de sociología, v. 73, n. 1, 2011. 
of a new environmental rationality under a sustainable guideline. Currently, it is discussed in terms of the "Environmental rule of law" or "Sustainable State." In the economic field, there are two applicable notions: "eco-capitalism" and "green economy."

The United Nations Environment Programmme (UENP) defined "green economy" as an economic development model that "results in improved human well-being and social equity, while significantly reducing environmental risks and ecological scarcities." ${ }^{\text {69 }}$

Eco-capitalism in turn is the combination of environmental and market principles. In a broad sense, there is an intrinsic relationship between economy and environment because economic systems are institutionalized processes of interaction between human beings and the environment. In other words, economic processes are framed by environment: This is both the source of resources and destination of waste. ${ }^{70}$ The notion of eco-capitalism is not, however, immune from criticism. In addition to Žižek, one can refer to Michael Löwy, ${ }^{71}$ Enrique Leff, ${ }^{72}$ and Juarez Freitas. ${ }^{73}$

In the same line, with a critical undertone, Serge Latouche argues:

When you are in Rome and you want to go to Turin, and if you are, by mistake, on the train to Naples, it is not enough to slow down the train, to break, or even to stop, you must go down and take another train in the opposite direction. To save the planet and guarantee an acceptable future to our children, it is not enough to moderate current trends, we

${ }_{68}$ FREITAS, Juarez. Sustentabilidade: direito ao futuro. 4. ed. Belo Horizonte: Fórum, 2019. p. 285.

${ }^{69}$ KREIBIHEL, Silvia; PATEL, Shilpa. Delivering the green economy through financial policy. Inquiry into the design of a sustainable financial system: policy innovations for a green economy. Frankfurt School of Finance \& Management-UNEP Collaborating Centre for Climate \& Sustainable Energy Finance, 2014. Available at: http://unepinquiry.org/wp-content/uploads/2014/05/141017_ UNEP-Inquiry-Green-Economy-through-Financial-Policy-3.pdf. Accessed: 11 Mar. 2021. p. 4.

70 POTTIER, Antonin. Le capitalisme est-il compatible avec les limites écologiques? Paris: Veblen Institute for Economic Reforms, 2017. Available at: https://www.veblen-institute.org/IMG/pdf/texte_veblen.pdf. Accessed: 11 Mar. 2021. p. 1.

71 Cf. LÖWY, Michael. Crise ecologique, capitalisme, altermondialisme. Un point de vue eco-socialiste. Novos cadernos NAEA, v. 11, n. 2, p. 5-14, 2008. Available at: https://periodicos.ufpa.br/index.php/ ncn/article/download/269/417. Accessed: Mar. 11, 2021.

72 Cf. LEFF, Enrique. Decrecimiento o desconstrucción de la economia: hacia um mundo sustentable. Revista de la Universidad Bolivariana, v. 7, n. 21, 2008.

73 FREITAS, Juarez. Sustentabilidade: direito ao futuro. 4. ed. Belo Horizonte: Fórum, 2019. p. 127-129. must squarely escape development and economi$\operatorname{cism}[\ldots]^{74}$

Nevertheless, ecology becomes an economic regulation paradigm in order to provide a capitalist economy an identity. ${ }^{75}$ This identity is found through ESG investments. "ESG" is the acronym for "environmental, social, and governance" and its parameters are used in the "analysis, selection and management of investments." In a descriptive and analytical form, the " $E$ " issue can be exemplified by a concern with "climate change, carbon emissions, pollution, resource efficiency, and biodiversity." The "S" includes "human rights, labor standards, health and safety, diversity policies, community relations, and development of human capital (health and education)." Under G, "corporate governance, corruption, the rule of law, institutional strength, transparency" are key issues for consideration. ${ }^{76}$

ESG investments are linked to the demand for "investment that may bring important social or environmental benefits, such as community development loan funds or clean technology portfolios." ${ }^{\prime 77}$ ESG investment discussions entail that "socially responsible investors (SRIs) consider non-financial criteria (e.g., social responsibility performance) in their investment decisions, in addition to conventional criteria such as return, risk or liquidity." ${ }^{78}$

Companies realize that there is potential for gaining a business advantage through positive social and environmental behavior because the spirit of ESG and sus-

74 LATOUCHE, Serge. D'autres mondes sont possibles, pas une autre mondialisation. Revue du Mauss, v. 2, n. 20, 2002. Available at: https://www.cairn.info/load_pdf.php?ID_ARTICLE=RDM_020 _0077\&download=1. Accessed: Mar. 18, 2021, p. 87.

75 LEVASSEUR, Lionel. L'écologie, nouveau régulateur du capitalisme? Quaderni, n. 17, p. 79-89, 1992. Available at: https://www. persee.fr/docAsPDF/quad_0987-1381_1992_num_17_1_944.pdf. Accessed: 11 Mar. 2021. p. 86.

76 INDERST, Georg; STEWART, Fiona. Incorporating environmental, social and governance (ESG) factors into fixed income investment. Washington: The World Bank Group, 2018. Available at: https:/ /openknowledge.worldbank.org/bitstream/handle/10986/29693/125442-WPPUBLIC.pdf?sequence=5\&isAllowed $=\mathrm{y}$. Accessed: 01 Mar. 2021. p. 2.

77 CHEN, Li et. al. Social responsibility portfolio optimization incorporating ESG criteria. Journal of Management Science and Engineering, 2021, article in press. Available at: https://www.sciencedirect. com/science/article/pii/S209623202100007X. Accessed: 28 Feb. 2021. p. [1].

78 GARCÍA, Fernando et. al. Selecting Socially Responsible Portfolios: A Fuzzy Multicriteria Approach. Sustainability, special issue: sustainable financial markets, 2019. Available at: https://www.mdpi. com/2071-1050/11/9/2496. Accessed: Feb. 28, 2021, p. 1. 
tainable investing is in "promoting change by diverting capital resources toward companies that are more likely to acknowledge sustainability issues." ${ }^{\text {99 }}$

Thus, ESG investments become an important mechanism to improve governance and guarantee sustainability: When society and the state prioritize companies that include this type of concern in their agenda, this institutes a system of obligations, rewards, and incentives that leads to the self-limitation of some conducts on behalf of environmentally and socially responsible actions. ${ }^{80}$

Incentivizing and valuing ESG investments may be a key element of the disaster prevention regulatory framework. Therefore, it is possible to justify and explain the relationships among the three concepts in the following way: ESG investments include environmental, social, and governance concerns to profitable reasoning. The "ESG" is a new investment strategy_"a set of rules, beliefs, or assumptions that govern an investor's investment decisions." "1-by which ESG factors are researched and evaluated. ${ }^{82}$ Resultantly, ESG investors prefer to invest in companies and assets involving less harm to the environment and its human consequences or that devote resources to implementing palliative and compensatory measures.

The disaster prevention system implies services and works of civil defense related to the improvement of environmental and social conditions. Consequently, governmental activity is necessary to make these investments more competitive, allowing a continuous flow of resources. Tax incentives are important because they make these investments more attractive. Therefore, since the State is enabled "to distinguish between admissible and non-admissible investments," 83 it is allowed to provide benefits to stimulate the admissible ones.

79 DE FRANCO, Carmine; NICOLLE, Johann; TRAN, Lan-Anh. Sustainable investing: ESG versus SDG. Available at: https://www. ossiam.fr/files/research_papers/1612454078_Sustainable_investing_ESG_versus_SDG.pdf. Accessed: 28 Feb. 2021. p. 1.

80 HOLMES, Stephen; SUNSTEIN, Cass R. O custo dos direitos: porque a liberdade depende dos impostos. São Paulo: WMF Martins Fontes, 2019. p. 127.

81 SHERWOOD, Matthew W.; POLLARD, Julia. Responsible investing: an introduction to environmental, social and governance investments. London, New York: Routledge, 2019. p. 1

82 SHERWOOD, Matthew W.; POLLARD, Julia. Responsible investing: an introduction to environmental, social and governance investments. London, New York: Routledge, 2019. p. 3.

83 MONEBHURRUN, Nitish. Is investment arbitration an appropriate venue for environmental issues? A Latin American perspec-

\section{Possibility of using tax incentives in ESG investments as a risk management and mitigation solution}

A disaster preventive system involves a regulatory framework, i.e., a set of rules directed toward regulating behaviors and imposing duties through the introduction of rewarding incentives or punitive disincentives. Disaster law is, most importantly, provided by legislative action and through administrative law. Therefore, disaster prevention shall be regulated through rules that will ultimately be applied primarily by the public administration.

In short, disaster law, because of its preventive nature, is not a type of law that sets out rules trusting to the good sense of each one, and then turning to the courts after they are violated to claim a redressal. While it is possible to resort to the judicial system for this purpose (expost facto action), or even for injuctive relief, disaster law manifests in public policies.

\subsection{Administrative disaster law and public policy-making}

Under the new "Environmental rule of law," there is a new role of the public adminstration on behalf of sustainability. In accordance with the Brazilian Constitution, Government shall have the duty to defend and preserve an ecologically balanced environment and healthy quality of life (Article 225). From the standpoint of disaster law, the state takes responsibility for promoting disaster prevention and the detection of environmentally risky situations, acting in a preventive manner in their management. ${ }^{84}$

This administrative duty to protect (Staatliche Schutzplichten) includes the development and execution of public policies and specifc programs and projects dedicated to mitigate the causes of natural or man-made disasters. ${ }^{85}$ In short, prevention of disasters and risk

tive. Revista de Direito Internacional, Brasília, v. 10, n. 1, p. 195-206, 2013. Available: https://www.publicacoesacademicas.uniceub.br/ rdi/article/view/2070/pdf. Accessed: 09 May. 2021. p. 202.

84 CARVALHO, Délton Winter de; DAMACENA, Fernanda Dalla Libera. Direito dos desastres. Porto Alegre: Livraria do Advogado, 2013. p. 120.

85 CARVALHO, Délton Winter de; DAMACENA, Fernanda Dalla Libera. Direito dos desastres. Porto Alegre: Livraria do Advogado, 
management involves administrative decisions and processes. ${ }^{86}$ As Carla Amado Gomes ${ }^{87}$ highlights, current risk/accident scenarios demand preventive public intervention.

Public policies are the adoption of a course of action aimed toward specific objectives. ${ }^{88}$ In other terms, they are state efforts responsive to the social demands, ${ }^{89}$ or instruments of public performance that aim to implement general principles of legal order. ${ }^{90}$ According to Trennepohl, ${ }^{91}$ public policies are a system with three subjects: the market, the state, and civil society.

A sustainable regulatory framework seeks to induce the adoption of good environmental practices. ${ }^{92}$ Therefore, the preventive role of administration in risk management involves the development of an incentive policy rooted in sustainable goals. This approach leads to the conclusion that "sustainable development needs to make the market compatible with the social constitutional concerns because it is believed that combining social responsibility, sustainable development, technology and tax incentives society can achieve improved quality of

2013. p. 81.

86 CARVALHO, Délton Winter de; DAMACENA, Fernanda Dalla Libera. Direito dos desastres. Porto Alegre: Livraria do Advogado, 2013. p. 35, p. 45.

87 GOMES, Carla Amado. Subsídios para um quadro principiológico dos procedimentos de avaliação e gestão do risco ambiental. Revista de Estudos Constitucionais, Hermenêutica e Teoria do Direito (RECHTD), v. 3, n. 2, 2011. Available at: http://revistas.unisinos.br/ index.php/RECHTD/article/download/1399/1767. Accessed: 13 Mar. 2021. p. 142.

88 TERENZI, Gabriel Vieira. Preferências eleitorais como referência ao controle jurisdicional de políticas públicas. In: GOMES, Daniel Machado; SALLES, Denise Mercedes Lopes; RABELLO, Elaine Teixeira; CAVALCANTI, Marcia Teixeira (org.) Teoria e empiria das políticas públicas. Rio de Janeiro: FGB / Pembroke Collins, 2020. p. 34.

89 CUSTÓDIO, André Viana; FREITAS, Higor Neves de. As políticas socioassistenciais na prevenção e erradicação do trabalho infantil. Revista de Direito Econômico e Socioambiental, Curitiba, v. 11, n. 2, p. 224-253, maio/ago. 2020. Available at: https://periodicos.pucpr. br/index.php/direitoeconomico/article/download/27088/24734. Accessed: 13 Mar. 2021. p. 238.

90 RIBAS, Lídia Maria; PINHEIRO, Hendrick.Taxa de resíduos sólidos como instrumento para promoção do Direito Fundamental ao Meio Ambiente Equilibrado. Revista de Direito Econômico e Socioambiental, Curitiba, v. 10, n. 2, p. 233-260, maio/ago. 2019. Available at: https://periodicos.pucpr.br/index.php/direitoeconomico/article/ download/23915/24220. Accessed: 13 Mar. 2021. p. 241.

91 TRENNEPOHL, Terence Dorneles. Incentivos fiscais no direito ambiental para uma matriz energética limpa e o caso do etanol brasileiro. 2. ed. São Paulo: Saraiva, 2011. p. 99.

92 FREITAS, Juarez. Sustentabilidade: direito ao futuro. 4. ed. Belo Horizonte: Fórum, 2019. p. 260. life, with the satisfaction of basic needs." ${ }^{\text {93 }}$ Against this background, taxation plays an important role in disaster prevention through the establishment of special market conditions and stimulating mechanisms.

\subsection{The role of taxation in disaster risk mitigation}

Public and private entities act dangerously-whether knowingly or not - contributing to the occurrence of disasters. On the other hand, a public adminstration under the "Environmental Rule of Law" should adopt legal rules and obligatory regulations to control the development of activies that put human life and environment at risk. ${ }^{94}$

Notwithstanding that taxes are destined to raise funds, they can be used with a stimulative purpose (extrafiscal function), becoming an instrument of social, economic, or environmental policy. ${ }^{95}$ For instance, the "polluter pays" principle legitimizes the imposition of taxes in order to encourage or discourage conducts and activities based on their potential for harm to the environment, i.e., "taxation assumes the role of an economic instrument in environmental policies which seeks to induce the adoption of behaviors" that are in harmony with the conservation of natural resources. ${ }^{96}$

For instance, the Constitution of the State of Paraná (Article 132) provides special treatment in tax revenue sharing for municipalities with unities of environmental

93 PSCHEIDT, Kristian Rodrigo. Social development and private health care system: three ways for success. Revista de Direito Econômico e Socioambiental, Curitiba, v. 6, n. 2, p. 29-49, jul./dez. 2015. Available at: https://periodicos.pucpr.br/index.php/direitoeconomico/article/download/5762/5690. Accessed: 13 Mar. 2021. p. 35-36.

94 CARVALHO, Délton Winter de; DAMACENA, Fernanda Dalla Libera. Direito dos desastres. Porto Alegre: Livraria do Advogado, 2013. p. $96-98$.

95 RABBANI, Roberto Muhákir Rahnemay. Poluição Sonora e proteção ambiental: intervenção estatal atual e possibilidade da tributação ambiental. Revista de Direito Econômico e Socioambiental, Curitiba, v. 7, n. 2, p. 03-21, jul. /dez. 2016. Available at: https:// periodicos.pucpr.br/index.php/direitoeconomico/article/download/5789/5720. Accessed: 13 Mar. 2021. p. 14; TRENNEPOHL, Terence Dorneles. Incentivos fiscais no direito ambiental para uma matriz. energética limpa e o caso do etanol brasileiro. 2. ed. São Paulo: Saraiva, 2011. p. 114.

96 RIBAS, Lídia Maria; PINHEIRO, Hendrick.Taxa de resíduos sólidos como instrumento para promoção do Direito Fundamental ao Meio Ambiente Equilibrado. Revista de Direito Econômico e Socioambiental, Curitiba, v. 10, n. 2, p. 233-260, maio/ago. 2019. Available at: https://periodicos.pucpr.br/index.php/direitoeconomico/article/ download/23915/24220. Accessed: 13 Mar. 2021. p. 244. 
conservation. ${ }^{97}$ Minas Gerais enacted Law No. 18.030, in January 12, 2009, whereby the State tax on goods circulation (ICMS) shall be proportionately assigned to the municipalities in accordance with their level of environmental conservation and basic sanitation. ${ }^{98}$

Similarly, it is possible to use tax mechanisms for disaster prevention. In truth, this understanding is not new. Arthur Cecil Pigou, in his Economics of Welfare of 1920, developed the idea of a tax destined to adjust for externalities. He states, "it is evident, in general, industrialists are interested, not in social, but only in the trade, net product of their operations." 99 Therefore, it would be up to the state to promote "extraordinary encouragements" or "extraordinary restraints" through bounties or taxes. ${ }^{100}$

Fourty years later, in 1960, the 1991 Nobel Laureate in Economics, Ronald Coase, wrote in his article, "The problem of social cost," about "actions of business firms which have harmful effects on others," with a critical approach of Pigouvian thought. However, even he recognizes that "a system in which the rights of individuals were unlimited would be one in which there were no rights to acquire." 101 In this vein, government should guarantee rights will not be misused. ${ }^{102}$ However, for Coase the main role should be played by the market, and not by lawyers, courts, or governmental intervention. ${ }^{103}$

Coase further states, "the cost of exercising a right (of using a factor of production) is always the loss whi-

\footnotetext{
97 TRENNEPOHL, Terence Dorneles. Incentivos fiscais no direito ambiental para uma matriz energética limpa e o caso do etanol brasileiro. 2. ed. São Paulo: Saraiva, 2011. p. 101.

98 MINAS GERAIS. Law n. 18.030, of January 12, 2009. Available at: https://www.almg.gov.br/consulte/legislacao/completa/completanova-min.html?tipo $=$ LEI\&num $=18030 \&$ ano $=2009$. Accessed: 14 Mar. 2021.

99 PIGOU, Arthur Cecil. The economics of welfare. London: Macmillan, 1920. p. 149.

100 PIGOU, Arthur Cecil. The economics of welfare. London: Macmillan, 1920. p. 168.

101 COASE, Ronald. The problem of social cost. Journal of Law and Economics, v. 3, p. 1-44, oct. 1960. Available at: http://home.cerge-ei. cz/ortmann/UpcesCourse/Coase $\% 20-\% 20$ The $\% 20$ problem $\% 20$ of $\% 20$ Social $\% 20$ Cost.pdf. Accessed: 13 Mar. 2021. p. 44.

102 HOLMES, Stephen; SUNSTEIN, Cass R. O custo dos direitos: porque a liberdade depende dos impostos. São Paulo: WMF Martins Fontes, 2019. p. 154.

103 COASE, Ronald. The problem of social cost. Journal of Law and Economics, v. 3, p. 1-44, oct. 1960. Available at: http://home.cerge-ei. cz/ortmann/UpcesCourse/Coase $\% 20-\% 20$ The $\% 20$ problem $\% 20$ of $\% 20$ Social $\% 20$ Cost.pdf. Accessed: 13 Mar. 2021. p. 18.
}

ch is suffered elsewhere in consequence of the exercise of that right," 104 which means that to grant someone a right implies subjecting other people to the effects of these rights. ${ }^{105}$ Therefore, with the recognition of the right to an ecologically balanced environment, there is a respective duty to take environmental responsible action. In line with Coase, "the problem is to avoid the more serious harm," i.e., "what has to be decided is whether the gain from preventing the harm is greater than the loss which would be suffered elsewhere as a result of stopping the action which produces the harm." "106 There is no doubt that disaster prevention is a greater gain than those obtained by the unregulated development of risky activities.

Karl William Kapp, also discussing social cost, proposed the adoption of social and ecological indicators that can guide the definition of the objectives to be achieved and the choice of paths to be followed under a preventive guidance. ${ }^{107} \mathrm{He}$ states, "the principle of social economy demands, moreover, that investments be made in such a fashion as to overcome the cumulative tendencies toward inequality and regional backwardness," namely "in harmony with technical and social criteria," and in line with minimum standards "for the maintenance of the life and health of all members of the society." 108

He argues that "the aim of economic science is to establish theoretical frameworks which show the possible relationships which connect the many variables of economic reality, thereby enabling individuals and governments to make reasoned choices in full understanding of the probable consequences of their action," i.e., economics must explore "the repercussions of alter-

104 COASE, Ronald. The problem of social cost. Journal of Law and Economics, v. 3, p. 1-44, oct. 1960. Available at: http://home.cerge-ei. cz/ortmann/UpcesCourse/Coase $\% 20-\% 20$ The $\% 20$ problem $\% 20$ of $\% 20$ Social $\% 20$ Cost.pdf. Accessed: 13 Mar. 2021, p. 44.

105 NEVES, Vitor. O problema dos custos sociais. In: CENTEMERI, Laura; CALDAS, José Castro (coord.). Valores em conflito: megaprojetos, ambiente e território. Coimbra: Almedina, 2016. p. 66.

106 COASE, Ronald. The problem of social cost. Journal of Law and Economics, v. 3, p. 1-44, oct. 1960. Available at: http://home.cerge-ei. cz/ortmann/UpcesCourse/Coase $\% 20-\% 20$ The $\% 20$ problem $\% 20$ of\%20Social\%20Cost.pdf. Accessed: 13 Mar. 2021. p. 2, p. 27.

107 NEVES, Vitor. O problema dos custos sociais. In: CENTEMERI, Laura; CALDAS, José Castro (coord.). Valores em conflito: megaprojetos, ambiente e território. Coimbra: Almedina, 2016. p. 81.

108 KAPP, Klaus William. The social costs of business enterprise. Nottingham: Spokesman, 1978. p. 295. 
native measures of public control and economic planning" and "formulate valid criteria for public decisions and public administration." 109

In his approach, "instead of conceiving of wealth and production merely in terms of exchangeable utilities, the new concepts of wealth and production will have to be defined in such a manner as to include non-pecuniary values," sustainable development and ESG investments, that are based on non-financial concerns: "everything that is considered useful and important from the standpoint of the nation whether exchangeable or not exchangeable, privately appropriable or socially beneficial."'111

We purpose this similarity and rapprochement among Kapp's thought, sustainable development, and ESG investments precisely because they all assimilate new reasoning and points of view on economic concerns, adopting a qualitative instead of a quantitative approach. The current society involves complex demands and the knowledge fields become more enmeshed and interlinked with each other. In this way, concepts that originally look decoupled in the truth are founded on dialogic epistemological bases.

Kapp's intention of introducing non-pecuniary values meets the sustainable development concept in that this notion comprehends more than the simple capital accumulation, but recognizes the importance of other concerns like social inclusion, income distribution, and improvement in social development indicators. ${ }^{112}$ Among these additional concerns, there is environmental conservation demanding economic incentives. ${ }^{113}$

As Magno Federici Gomes and Luís Eduardo Gomes $^{114}$ note, true development only exists when it is

\footnotetext{
109 KAPP, Klaus William. The social costs of business enterprise. Nottingham: Spokesman, 1978. p. 283.

110 KAPP, Klaus William. The social costs of business enterprise. Nottingham: Spokesman, 1978. p. 290.

111 KAPP, Klaus William. The social costs of business enterprise. Nottingham: Spokesman, 1978. p. 290.

112 GOMES, Magno Federici; SILVA, Luís Eduardo Gomes. BRICS: Desafios do desenvolvimento econômico e socioambiental. Revista de Direito Internacional, Brasília, v. 14, n. 1, p. 341-356, 2017. Available: https://www.publicacoesacademicas.uniceub.br/rdi/article/view/4449/pdf. Accessed: 05 May. 2021. p. 344.

113 GOMES, Magno Federici; SILVA, Luís Eduardo Gomes. BRICS: Desafios do desenvolvimento econômico e socioambiental. Revista de Direito Internacional, Brasília, v. 14, n. 1, p. 341-356, 2017. Available: https://www.publicacoesacademicas.uniceub.br/rdi/article/view/4449/pdf. Accessed: May 05, 2021. p. 345-346.

114 GOMES, Magno Federici; SILVA, Luís Eduardo Gomes.
}

based on sustainable management on behalf of the benefit of the collectivity. That is, "economic activities of transnational companies may insidiously meander towards many non-economic components of the host States' society thereby causing considerable damage to the local population, environment, values or culture."115 On this basis, "the idea is to transcend the inner corporate structure and the sole shareholder's interests, thereby setting up a business intelligence which is able to envisage and eventually prevent a company's adverse social impacts." 116

In this way, the introduction of ESG issues in the investor's decision-making process also represents a behavior change in the sense of social responsibility, that is, the investor not only worries about the financial performance of its assets but how its investments influence the real world. Consequently, ESG investments are a new paradigm that incorporate the same theoretical foundations of Kapp's thought and sustainable development: "the investment activities are expected to foster environmental progress in view of sustainable development."117 In other words, investors "articulate their activities with other values, may these be the respect of the environment, of human rights, of local communities and culture, of ethics and transparency." 118

BRICS: Desafios do desenvolvimento econômico e socioambiental. Revista de Direito Internacional, Brasília, v. 14, n. 1, p. 341-356, 2017. Available: https://www.publicacoesacademicas.uniceub.br/rdi/article/view/4449/pdf. Accessed: 05 May. 2021. p. 352.

115 MONEBHURRUN, Nitish. Mapping the Duties of Private Companies in International Investment Law. Revista de Direito Internacional, Brasília, v. 14, n. 2, p. 49-71, 2017. Available: https:// www.publicacoesacademicas.uniceub.br/rdi/article/view/4860. Accessed: 05 May. 2021. p. 51.

116 MONEBHURRUN, Nitish. Mapping the Duties of Private Companies in International Investment Law. Revista de Direito Internacional, Brasília, v. 14, n. 2, p. 49-71, 2017. Available: https:// www.publicacoesacademicas.uniceub.br/rdi/article/view/4860. Accessed: 05 May. 2021. p. 54.

117 MONEBHURRUN, Nitish. Novelty in International Investment Law: The Brazilian Agreement on Cooperation and Facilitation of Investments as a Different International Investment Agreement Model. Journal of International Dispute Settlement, v. 8, 2017. Available: https://www.researchgate.net/publication/290474976_ Novelty_in_International_Investment_Law_The_Brazilian_Agreement_on_Cooperation_and_Facilitation_of_Investments_as_a_ Different_International_Investment_Agreement_Model. Accessed: 08 May. 2021. p. 96.

118 MONEBHURRUN, Nitish. Mapping the Duties of Private Companies in International Investment Law. Revista de Direito Internacional, Brasília, v. 14, n. 2, p. 49-71, 2017. Available: https:// www.publicacoesacademicas.uniceub.br/rdi/article/view/4860. Accessed: 05 May. 2021. p. 60. 
Therefore, by definition, ESG investment "aims to combine better risk management with improved portfolio returns, and to reflect investor and beneficiary values in an investment strategy." 119 For instance, instead of making an investment decision based only on the profit provided by the asset, the investor chooses to invest in companies that do not test on animals or consider the number of women in leadership positions.

Changing economic behavior "can be voluntarily set by the companies themselves in the sense of a self-regulation" or "be provided for in binding legal instruments." 120 Law influences conduct, independent of the penalties it imposes ${ }^{121}$. Nowadays, the already mentioned increasing concern with ESG investments may be incentivized by tax policies: "taxation and public spending are concerned with the process of adjusting scarce means to competing ends."

The determination of budgets is a process of decision-making in which the selection of different public goals and the extent of their gratification are determined." 122 Indeed, the role of taxation in disaster prevention, or, in a broad sense, in environmental protection, is not only to introduce new taxes over negative behaviors and activities, but also tax relief mechanisms over positive and desirable conducts, goods, and services.

\subsection{Tax incentives in ESG investments as precautionary public policy against disaster risks}

Carvalho and Damacena ${ }^{123}$ argue that disaster, both natural or man-made, can be avoided or mitigated if an impact assessment is made before some activity or

\footnotetext{
119 BOFFO, Ricardo, PATALANO, Robert. ESG Investing: Practices, Progress and Challenges. Paris: OECD, 2020. Available: www. oecd.org/finance/ESG-Investing-Practices-Progress-and-Challenges.pdf. Accessed: 09 May. 2021. p. 11.

120 MONEBHURRUN, Nitish. Mapping the Duties of Private Companies in International Investment Law. Revista de Direito Internacional, Brasília, v. 14, n. 2, p. 49-71, 2017. Available: https:// www.publicacoesacademicas.uniceub.br/rdi/article/view/4860. Accessed: 05 May. 2021. p. 54.

121 Acc. McADAMS, Richard H. A focal point theory of expressive law. Law and economics working paper series, working paper n. 00-14, 2000.

122 KAPP, Klaus William. The social costs of business enterprise. Nottingham: Spokesman, 1978. p. 291.

${ }^{123}$ CARVALHO, Délton Winter de; DAMACENA, Fernanda Dalla Libera. Direito dos desastres. Porto Alegre: Livraria do Advogado, 2013. p. 107.
}

enterprise. The main guideline behind this standpoint is the precautionary principle, a pillar of any disaster prevention system that compels the adoption of risk reduction measures. ${ }^{124}$ In economic terms, this adoption of some behavior is induced by incentives, i.e., "something that induces a person to act, such as the prospect of a punishment or a reward." Therefore, "public policy makers should never forget about incentives: Many policies change the costs or benefits that people face and, therefore, alter their behavior." 125 As stated above, taxation is an important mechanism of incentives.

N. Gregory Mankiw points out that "a rational decision maker takes an action if and only if the marginal benefit of the action exceeds the marginal cost." ${ }^{126}$ As Daniel Farber ${ }^{127}$ argues, individuals require compensations for delaying consumption and investing their funds. Therefore, if there is a social purpose for preventing disasters and protecting the environment, a regulation, aimed at making the benefits of environmental and social responsible investments higher than their costs, should be implemented.

Therefore, to achieve the objective of contributing to a new rationality, founded on environmental and social concerns, ESG investments should be made more attractive than other types of business conducts and corporate practices (trade-offs). The issue is not a Gordian knot, but truly quite simple: investors will choose ESG investments not only because they are founded on good intentions, but more on their cost-effectiveness relation. Notably, if the return on investment is large enough to persuade individuals to invest their money, then environmental investments may offer higher long-term returns. ${ }^{128}$ If prevention is less advantageous than

124 CARVALHO, Délton Winter de; DAMACENA, Fernanda Dalla Libera. Direito dos desastres. Porto Alegre: Livraria do Advogado, 2013. p. 89.

125 MANKIW, Nicholas Gregory. Principles of microeconomisc. 5. ed. Mason: South-Western Cengage Learning, 2008. p. 7.

126 MANKIW, Nicholas Gregory. Principles of microeconomisc. 5. ed. Mason: South-Western Cengage Learning, 2008. p. 6.

127 FARBER, Daniel. From here to eternity: environmental law and future generations. University of Illinois Law Review, n. 2, 2003. Available at: https://illinoislawreview.org/print/volume-2003-issue-2/ from-here-to-eternity-environmental-law-and-future-generations/. Accessed: 20 Mar. 2021. p. 297.

128 FARBER, Daniel. From here to eternity: environmental law and future generations. University of Illinois Law Review, n. 2, 2003. Available at: https://illinoislawreview.org/print/volume-2003-issue-2/ from-here-to-eternity-environmental-law-and-future-generations/. Accessed: 20 Mar. 2021. p. 297-301. 
reparatory costs, there will be no incentive for disaster prevention $^{129}$.

Notwithstanding, it is important to highlight the stock market is facing an increase in the number of individual investors, and more than just a quantitative matter, this represents a profile change. Therefore, it is inappropriate to presume that all of these new individuals seeking more aggressive investments have the financial knowledge levels and experience necessary to properly define the best assets. Indeed, the philosophical intention behind this article's purpose is to reconcile environmental concerns with the democratization of financial markets, recognizing the role of the State in providing financial education, and the use of these factors to incentivitize a wide environmental cultural spread through the society.

Against the background mentioned above, Mexican legislation included the use of market-based instruments, incentives, and other measures that improve the cost/benefit relation of mitigation measures through the decrease of context costs (Article 33, II of General Law for Climate Change). ${ }^{130}$

In judicial language, the reasoning behind this approach is the concept of positive sanctions, which is a natural corollary of the precautionary principle and preventive management of adverse situations. As Celso Lafer ${ }^{131}$ says about Bobbio's work, the role of law is not simply allow or forbid, but also promote and encourage through incentives and disincentives. In the context of Brazilian environmental tax law, the notion of positive sanctions was addressed by Terence Dorneles Trennepohl regarding tax incentives for the clean energy grid. $^{132}$

\footnotetext{
129 BRASIL, Deilton Ribeiro; AYALA, Vinicius de Araujo. Uma construção necessária do conceito de dano ambiental futuro: responsabilidade civil e teoria do risco abstrato. In: SILVA FILHO, Erivaldo Cavalcanti e; SOUZA, José Fernando Vidal de; PADILHA, Norma Sueli. Direito ambiental e socioambientalismo I. Florianópolis: CONPEDI, 2018. p. 277-278.

${ }^{130}$ MEXICO. General Law for Climate Change. Available: https:// www.profepa.gob.mx/innovaportal/file/6583/1/ley_general_de_ cambio_climatico.pdf. Accessed: 16 Mar. 2021.

131 LAFER, Celso. Da estrutura à função: o olhar de Bobbio sobre a função promocional do direito. In: LAFER, Celso. Norberto Bobbio: trajetória e obra. São Paulo: Perspectiva, 2013. p. 171.

132 TRENNEPOHL, Terence Dorneles. Incentivos fiscais no direito ambiental para uma matriz energética limpa e o caso do etanol brasileiro. 2. ed. São Paulo: Saraiva, 2011. p. 45-52.
}

The following examples provide an overview of this thesis. Carvalho and Damacena ${ }^{133}$ state that the occupation of risky areas plays a key role in the occurrence of a disaster. Therefore, it is possible to incentivize social actions or project financing arrangements destined to provide adequate infrastructure or even to move people away from these unsafe areas for habitable places. In fact, this public policy is appropriate under Article $5^{\circ}$, XI, and XII of Law No. 12.608, of April 10, $2012,{ }^{134}$ which stipulates the duty to combat the occupation of vulnerable areas, promote residential relocation, and stimulate safe housing programs.

Other situation is biodiversity and natural resource conservation. ${ }^{135}$ In the same way, it is possible to induce the adoption and financing of environment preservation and reforestation projects. Historically, Brazilian tax law includes the possibility of deducting reforestation spending from income tax, for instance in the former Law No. 5.106, of September 2nd, 1966, ${ }^{136}$ and Article 41, §1, II of Law No. 12.651 of May 25, 2012. ${ }^{137}$ Trennepohl ${ }^{138}$ lists some examples of tax incentives in the federal, state, and municipal spheres.

Incentivizing ESG investments can take place throught different ways: relieving tax costs of ESG investments in stock market, and acting on corporate practices to make legal persons act in accordance with ESG criteria. If ESG investments become more attractive to investors, they will allocate their resources in ESG assets, generating a substantial flow of capital, which consequently might influence and encourage other companies. Moreover, incentivizing structural measures by companies will make them more attractive to investors, who are seeking ESG-rated companies to invest in.

133 CARVALHO, Délton Winter de; DAMACENA, Fernanda Dalla Libera. Direito dos desastres. Porto Alegre: Livraria do Advogado, 2013. p. 48.

134 BRASIL. Law n. 12.608, of April 10, 2012. Available at: http:// www.planalto.gov.br/ccivil_03/_ato2011-2014/2012/lei/112608. htm. Accessed: 15 Mar. 2021.

135 CARVALHO, Délton Winter de; DAMACENA, Fernanda Dalla Libera. Direito dos desastres. Porto Alegre: Livraria do Advogado, 2013. p. 59.

136 BRASIL. Law n. 5.106, of May 02nd, 1966. Available at: http:// www.planalto.gov.br/ccivil_03/leis/1950-1969/15106.htm. Accessed: 15 Mar. 2021.

137 BRASIL. Law n. 12.651, of May 25, 2012. Available at: http:// www.planalto.gov.br/ccivil_03/_ato2011-2014/2012/lei/112651. htm. Accessed: 15 Mar. 2021.

138 TRENNEPOHL, Terence Dorneles. Incentivos fiscais no direito ambiental para uma matriz energética limpa e o caso do etanol brasileiro. 2. ed. São Paulo: Saraiva, 2011. p. 105-107. 
Regarding the first situation, there are two stock indices used by the Brazilian stock exchange that indicate sustainable and environmental responsible companies - the Carbon Efficient Index (ICO2 B3) and Corporate Sustainability Index (ISE B3). Two perspectives are applicable here. First, it is possible to introduce a similar regulatory framework as with incentivized debentures. Second, listed companies may obtain tax relief proportionally to their actions toward a low-carbon-economy transition, in the case of ICO2 $\mathrm{B} 3$, or in accordance with the level of integration of the U.N. sustainable development goals in their corporate strategies and processes in the case of ISE B3. ${ }^{139}$

A taxonomy of tax incentives is still necessary for a better understanding of the propositions in this article. Tax incentives are the genus and may consist of tax immunity, tax exemption, deferral, tax remission, or tax amnesty. ${ }^{140}$ For instance, a tax regulatory framework to prevent disasters may include the following. ${ }^{141}$

a) tax exemption of the manufacture, import, and commercialization of electric vehicles, or else the application of differentiated aliquot recollection of Vehicle Property Tax and Vehicle Licensing Fee;

b) tax exemption or differentiated aliquot in accordance with energy consumption, waste generation, and water consumption, or in case of the implementation of rain water, recuperation systems;

c) tax exemption of the Causa Mortis Transfer and Donation Tax (ITCMD), as in the State of São Paulo for donations regarding housing programs (Article 6, II, b of Law No. 10.705, of December 28, 2000). ${ }^{142}$ In this line, it is possible to allow income tax deduction if the donation was designed for environmental and social funds, organizations, or projects. One current example: South Africa has passed a bill allowing income tax deduction of amounts

\footnotetext{
139 B3. B3 divulga a $16^{a}$ carteira do ISE B3. Available at: https:/ / iseb3site.s3.amazonaws.com/Release_2020.pdf. Accessed: 12 Mar. 2021. 140 TRENNEPOHL, Terence Dorneles. Incentivos fiscais no direito ambiental para uma matriz energética limpa e o caso do etanol brasileiro. 2. ed. São Paulo: Saraiva, 2011. p. 124.

${ }^{141}$ For an overview of international green taxation, see "The KPMG Green Tax Index: an exploration of green tax incentives and penalties," available at: https://assets.kpmg/content/dam/kpmg/ tw/pdf/2017/09/655445_NSS_2017Green_TaxIndex_v18web. pdf. Accessed: 16 Mar. 2021.

142 SÃO PAULO. Law n. 10.705, of December 28, 2000. Available at: https://legislacao.fazenda.sp.gov.br/Paginas/lei10705.aspx. Accessed: 16 Mar. 2021.
}

donated to COVID-19 disaster relief organization or Solidarity Funds; ${ }^{143}$

d) proportional taxation depending on the level of the use of agrotoxics (the lower the use of agrotoxics, the lower the tax rates). It is also possible to allow income tax deduction of the expenses related to organic production, or even allow the deduction of organic production areas in Rural Territorial Property Tax (ITR) or Urban Building and Land Tax (IPTU), as happens with environmental preservation areas;

e) exemption of the tax on services (ISS) regarding reforestation services;

f) non-incidence of improvement taxes regarding real estate owners benefited by disaster prevention works. In this sense, the Decree-Law n. $195 / 1967^{144}$, which provides a taxonomy of public works that can be financed by special assessment tax, include allowing this tax to be levied against funding works related to defense against droughts, floods, and erosion (article 2, V). However, it should be amended to exclude the incidence of improvement tax in the case of works related to defense against droughts, floods and erosion. Additionally, the municipal tax codes which also predict this tax should be amended in this same sense;

g) tax incentives in donations and other actions regarding foster and support studies about disaster risk, vulnerability disaster reduction, and disaster management, as well as related to the development of projects and programs on these concerns. Investigating, learning, and propagating knowledge and information are the first step in disaster prevention. ${ }^{145}$

In addition to these tax incentives through structural measures, it is also possible to define a regulation related to investments in financial assets. The main guidelines under this thesis are the tax rules for incentivized debentures (as provided by Article 2nd of Law No. 12.431, June 24, 2011 $\left.{ }^{146}\right)$. Indeed, there are several possible situations:

a) Tax exemption, immunity, or income tax deduction of investments in environment-related

143 SOUTH AFRICA. Act n. 13 of 2020: Disaster management tax relief act, 2020. Available at: https://www.gov.za/sites/default/files/ gcis_document/202011/43883-gon1188.pdf. Accessed: 16 Mar. 2021.

144 BRASIL. Decree-Law n. 195/1967. Available at: https://www.planalto.gov.br/ccivil_03/decreto-lei/del0195.htm. Accessed: 17 Apr. 2021.

145 Cf. MACHADO, Paulo Affonso Leme. Direito à informação e meio ambiente. 2. ed. São Paulo: Malheiros, 2018.

146 BRASIL. Law n. 12.431, of June 24, 2011. Available at: http:// www.planalto.gov.br/ccivil_03/_Ato2011-2014/2011/Lei/L12431. htm. Accessed: 16 Mar. 2021. 
assets. For example, ESG funds may be excluded from the incidence of income tax.

b) Although nowadays dividends are exempt from income tax, a bill has been introduced to allow income tax to be charged on dividends (Bill No. 307/2021 ${ }^{147}$ ). This purpose is in fact not new-there have other simillar bills in the Brazilian legislature (e.g., Bills Nos. 1952/2019 and $2640 / 2020^{148}$ ). For this reason, such proposals, to encourage disaster prevention and environmental compliance, should exclude dividends distributed by companies engaged in environmentally friendly actions - as provided by the Argentinian "Legal Regulations on $\mathrm{Na}$ tional Promotion for the Use of Sources of Renewable Energy to Generate Electric Power Act." 149

c) Tax exemption for ESG funds regarding income tax, taxes on financial operations, or both.

Consequently, it is concluded that tax incentives are a useful mechanism to induce environmental protection and precautionary actions regarding the necessary infrastructure to prevent disasters.

\section{Conclusion}

Disaster prevention is an unavoidable necessity of current society for the survival of life on this Earth-not only human life, but also plant and animal life. Indeed, there are ample opportunities for disasters to strike, whether natural or caused by anthropogenic activity, including phenomena like earthquakes, landslides, volcanic eruptions, floods, hurricanes, tornadoes, blizzards, tsunamis, cyclones, pandemics, stampedes, fires, transport accidents, industrial accidents, oil spills, nuclear explosions, and nuclear radiation.

Preventing such situations demands responsibilities and behavior change that are often incompatible

\footnotetext{
147 BRASIL. Bill n. 307/2021. Available at: chrome-extension:// oemmndcbldboiebfnladdacbdfmadadm/https://www.camara.leg. $\mathrm{br} /$ proposicoesWeb/prop_mostrarintegra?codteor=1961664. Accessed: 16 Mar. 2021.

148 BRASIL. Bill n. 1952/2019. Available at: https://www25.senado.leg.br/web/atividade/materias/-/materia/136117. Accessed: 16 Mar. 2021; BRASIL. Bill n. 2640/2020. Available at: https:// www.camara.leg.br/proposicoesWeb/fichadetramitacao?idProposic ao $=2252638$. Accessed: 16 Mar. 2021.

149 ARGENTINA. Legal Regulations on National Promotion for the Use of Sources of Renewable Energy to Generate Electric Power Act. Available at: ttps://www.argentina.gob.ar/sites/default/files/ley_261902006_english_version.pdf. Accessed: 16 Mar. 2021.
}

with market preferences and the profit motive. However, this dissonance has been changed. Nowadays, there is an increasing concern of investors in resource allocation of assets that follow criteria that measure corporate governance, sustainability, and social responsibility.

Nevertheless, the profit rmotive remains and economic agents still move in accordance with incentives and benefits. Therefore, disaster prevention involves an economic approach achievable by tax means. From this standpoint, it is relevant to provide tax relief for environmentally and socially responsible investments.

As seen before, enviromental protection and disaster prevention through tax incentives in ESG investments can be accomplished through structural and non-structural measures. In other words, tax incentives are admissible regarding the capital flows and allocation of resources to assets through the stock market and to provide tax relief for structural actions adopted by companies in order to meet ESG criteria.

In conclusion, the adoption of tax incentives is the measure that can contribute most to disaster prevention, since it leads, a priori, to environmentally responsible actions. By contrast, positive taxation over environmental harmful behaviors, goods, and services encounters resistance on the basis of two arguments: the high tax burden and its ex post facto nature, because such tax is assessed on activities, services, goods, and deeds that have already damaged the environment.

The admissibility of tax incentives to ESG investments is founded on behaviorist approaches, both in law and economy. In this sense, they deal with how individuals make decisions in their daily routine. Taxation may promote development but may also limit growth opportunities. It may be a negative externality. Therefore, law must include economic and psychology methodological standards to provide the most effective regulation. Tax incentives allow disaster prevention system improvements without overburdening citizens or leaving them recalcitrant to environmental causes.

Notwithstanding, the relations between disaster prevention and the financial market cannot be taken into account only from the point of view related to the institutional adaption to the new green economy, but should also consider the increase of individual investors without previous experience or specific knowledge. Consequently, under the law's promotional role, it is necessary to join efforts, both public and private, to 
democratize and stimulate environmental and socially responsible investment choices.

Nowadays, sustainable development has to be the watchword. More than mere words, sustainability must be an effective world perspective. It is not only about being in the world, but also acting in the world. Therefore, sustainable actions must take place everyday through a holistic approach. The market should not be seen as an enemy: Its logic may be used as an efficient tool in favor of the environment, disaster prevention, and risk management.

\section{References}

ANTONIAZZI, Mariela Morales; PIOVESAN, Flávia; IGNÁCIO, Renata Rossi. Covid-19 e direitos econômicos, sociais, culturais e ambientais (DESCA): impacto dos estandares interamericanos. Revista de direito econômico e socioambiental, Curitiba, v. 11, n. 1, p. 59-90, jan./abr. 2020. Available at: https://periodicos.pucpr. br/index.php/direitoeconomico/article/download/27353/24621. Accessed: 03 Mar. 2021.

ARGENTINA. Legal Regulations on National Promotion for the Use of Sources of Renewable Energy to Generate Electric Power Act. Available at: ttps://www.argentina.gob.ar/sites/default/files/ley_26190-2006_english_version.pdf. Accessed: 16 Mar. 2021.

B3. B3 divulga a $16^{a}$ carteira do ISE B3. Available at: https://iseb3-site.s3.amazonaws.com/Release_2020. pdf. Accessed: 12 Mar. 2021.

BECK, Ulrich. Living in the world risk society. Economy and Society, v. 35, n. 3, p. 329-345, aug. 2006. Available at: https://edisciplinas.usp.br/pluginfile.php/4095470/ mod_resource/content/0/Beck--WorldRisk.pdf. Accessed: Mar. 05, 2021.

BECK, Ulrich. Risk society: towards a new modernity. London: SAGE Publications, 1992.

BOBBIO, Norberto. A era dos direitos. Rio de Janeiro: Elsevier, 2004.

BOFFO, Ricardo, PATALANO, Robert. ESG Investing: Practices, Progress and Challenges. Paris: OECD, 2020. Available: www.oecd.org/finance/ESG-Investing-Practices-Progress-and-Challenges.pdf. Accessed: May 09, 2021.
BOSSELMANN, Klaus. O princípio da sustentabilidade: transformando direito e governança. São Paulo: Revista dos Tribunais, 2015.

BOSSELMANN, Klaus; ENGEL, Ron; TAYLOR, Prue. Governance for sustainability: issues, challenges, successes. Gland: International Union for Conservation of Nature and Natural Resources, 2008.

BRASIL, Deilton Ribeiro; AYALA, Vinicius de Araujo. Uma construção necessária do conceito de dano ambiental futuro: responsabilidade civil e teoria do risco abstrato. In: SILVA FILHO, Erivaldo Cavalcanti e; SOUZA, José Fernando Vidal de; PADILHA, Norma Sueli. Direito ambiental e socioambientalismo I. Florianópolis: CONPEDI, 2018.

BRASIL. Bill n. 1952/2019. Available at: https:// www25.senado.leg.br/web/atividade/materias/-/materia/136117. Accessed: 16 Mar. 2021.

BRASIL. Bill n. 2640/2020. Available at: https://www. camara.leg.br/proposicoesWeb/fichadetramitacao?idPr oposicao=2252638. Accessed: 16 Mar. 2021.

BRASIL. Bill n. 307/2021. Available at: chromeextension:/ / oemmndcbldboiebfnladdacbdfmadadm/ https://www.camara.leg.br/proposicoesWeb/prop_ mostrarintegra?codteor=1961664. Accessed: 16 Mar. 2021.

BRASIL. Decree n. 10.593, of December 24, 2020. Available at: http://www.planalto.gov.br/ccivil_03/_Ato20192022/2020/Decreto/D10593.htm\#art42. Accessed: 06 Mar. 2021.

BRASIL. Decree-Law n. 195/1967. Available at: https:/ / www.planalto.gov.br/ccivil_03/decreto-lei/del0195. htm. Accessed: April 17, 2021.

BRASIL. Law n. 12.431, of June 24, 2011. Available at: http://www.planalto.gov.br/ccivil_03/_Ato20112014/2011/Lei/L12431.htm. Accessed: 16 Mar. 2021.

BRASIL. Law n. 12.608, of April 10, 2012. Available at: http://www.planalto.gov.br/ccivil_03/_ato20112014/2012/lei/112608.htm. Accessed: 15 Mar. 2021.

BRASIL. Law n. 12.651, of May 25, 2012. Available at: http://www.planalto.gov.br/ccivil_03/_ato20112014/2012/lei/112651.htm. Accessed: 15 Mar. 2021.

BRASIL. Law n. 5.106, of May 02nd, 1966. Available at: http://www.planalto.gov.br/ccivil_03/leis/1950-1969/ 15106.htm. Accessed: 15 Mar. 2021. 
CÂMARA, Ana Stela. Economic assumptions of the ecological state: looking for sustainability. Revista de Direito Econômico e Socioambiental, Curitiba, v. 10, n. 3, p. 50-66, set./dez. 2019. Available at: https://periodicos. pucpr.br/index.php/direitoeconomico/article/download/25687/24226. Accessed: 11 Mar. 2021.

CAMPOS, Alísson Thiago de Assis; BRASIL, Deilton Ribeiro. A internacionalização dos direitos humanos e a retomada das práticas restaurativas no processo penal. Rev. de Formas Consensuais de Solução de Conflitos, v. 3, n. 2, p. 01-18, jul./dez. 2017. e-ISSN: 2525-9679. Available at: https://www.indexlaw.org/index.php/revistasolucoesconflitos/article/view/2225/pdf. Accessed: 07 Mar. 2021.

CARVALHO, Délton Winter de. Desastres ambientais $e$ sua regulação jurídica: deveres de prevenção, resposta e compensação ambiental. 2. ed. São Paulo: Revista dos Tribunais, 2020.

CARVALHO, Délton Winter de; DAMACENA, Fernanda Dalla Libera. Direito dos desastres. Porto Alegre: Livraria do Advogado, 2013.

CENTRE FOR RESEARCH ON THE EPIDEMIOLOGY OF DISASTERS (CRED). EM-DAT Glossary. Available at: https://www.emdat.be/Glossary\#letter_d. Accessed: 06 Mar. 2021.

CHEN, Li et. al. Social responsibility portfolio optimization incorporating ESG criteria. Journal of Management Science and Engineering, 2021, article in press. Available at: https://www.sciencedirect.com/science/article/pii/ S209623202100007X. Accessed: 28 Feb. 2021.

COASE, Ronald. The problem of social cost. Journal of Law and Economics, v. 3, p. 1-44, oct. 1960. Available at: http://home.cerge-ei.cz/ortmann/UpcesCourse/ Coase $\% 20-\% 20$ The $\% 20$ problem $\% 20$ of $\% 20$ Social $\% 20$ Cost.pdf. Accessed: 13 Mar. 2021.

CUSTÓDIO, André Viana; FREITAS, Higor Neves de. As políticas socioassistenciais na prevenção e erradicação do trabalho infantil. Revista de Direito Econômico e Socioambiental, Curitiba, v. 11, n. 2, p. 224-253, maio/ ago. 2020. Available at: https://periodicos.pucpr. $\mathrm{br} /$ index.php/direitoeconomico/article/download/27088/24734. Accessed: 13 Mar. 2021.

DE FRANCO, Carmine; NICOLLE, Johann; TRAN, Lan-Anh. Sustainable investing: ESG versus SDG. Available at: https://www.ossiam.fr/files/research_pa-
pers/1612454078_Sustainable_investing_ESG_versus_SDG.pdf. Accessed: 28 Feb. 2021.

DWORKIN, Ronald. Levando os direitos a sério. São Paulo: WMF Martins Fontes, 2020.

EUROPEAN PARLIAMENT. Forsmark: how Sweden alerted the world about the danger of the Chernobyl disaster. May 15, 2014. Available at: https:// www.europarl.europa.eu/news / en / headlines / society/20140514STO47018/forsmark-how-swedenalerted-the-world-about-the-danger-of-chernobyl-disaster. Accessed: 06 Mar. 2021.

FARBER, Daniel. Disaster law and emerging issues in Brazil. Revista de Estudos Constitucionais, Hermenêutica e Teoria do Direito (RECHTD), v. 4, n. 1, 2012. Available at: http://www.revistas.unisinos.br/index.php/ RECHTD/article/view/rechtd.2012.41.01/932. Accessed: 04 Mar. 2021.

FARBER, Daniel. From here to eternity: environmental law and future generations. University of Illinois Law Review, n. 2, 2003. Available at: https:/ /illinoislawreview. org/print/volume-2003-issue-2/from-here-to-eternityenvironmental-law-and-future-generations/. Accessed: 20 Mar. 2021.

FISCHER, Horst. International disaster response law treaties: trends, patterns and lacunae. In: INTERNATIONAL FEDERATION OF RED CROSS AND RED CRESCENT SOCIETIES. International disaster response laws, principles and practice: reflections, prospects and challenges. Geneva: 2003. Available at: https:// www.ifrc.org/PageFiles/41194/idrl-book-c2.pdf. Accessed: 07 Mar. 2021.

FREITAS, Juarez. Sustentabilidade: direito ao futuro. 4. ed. Belo Horizonte: Fórum, 2019.

FUKUYAMA, Francis. The end of bistory and the last man. New York: The Free Press, 1992.

GARCÍA, Fernando et. al. Selecting Socially Responsible Portfolios: A Fuzzy Multicriteria Approach. Sustainability, special issue: sustainable financial markets, 2019. Available at: https://www.mdpi.com/20711050/11/9/2496. Accessed: 28 Feb. 2021.

GOMES, Carla Amado. Subsídios para um quadro principiológico dos procedimentos de avaliação e gestão do risco ambiental. Revista de Estudos Constitucionais, Hermenêutica e Teoria do Direito (RECHTD), v. 3, n. 2, 2011. Available at: http://revistas.unisinos.br/index. 
php/RECHTD/article/download/1399/1767. Accessed: 13 Mar. 2021.

GOMES, Magno Federici; SILVA, Luís Eduardo Gomes. BRICS: Desafios do desenvolvimento econômico e socioambiental. Revista de Direito Internacional, Brasília, v. 14, n. 1, p. 341-356, 2017. Available: https:// www.publicacoesacademicas.uniceub.br/rdi/article/ view/4449/pdf. Accessed: 05 May. 2021.

HÄGG, Conny. Consequences in Sweden of the Chernobyl accident. Stockholm: National Institute of Radiation Protection, 1990. Available at: https://inis.iaea.org/collection/NCLCollectionStore/_Public/21/071/21071159. pdf?r=1\&r=1. Accessed: 06 Mar. 2021.

HOLMES, Stephen; SUNSTEIN, Cass R. O custo dos direitos: porque a liberdade depende dos impostos. São Paulo: WMF Martins Fontes, 2019.

INDERST, Georg; STEWART, Fiona. Incorporating environmental, social and governance (ESG) factors into fixed income investment. Washington: The World Bank Group, 2018. Available at: https://openknowledge.worldbank. org/bitstream/handle/10986/29693/125442-WPPUBLIC.pdf? sequence $=5 \&$ is Allowed $=\mathrm{y}$. Accessed: 01 Mar. 2021

INTERNATIONAL FEDERATION OF RED CROSS AND RED CRESCENT SOCIETIES. Disaster law database. Available at: https://www.ifrc.org/en/ publications-and-reports/idrl-database/. Accessed: 07 Mar. 2021.

INTERNATIONAL FEDERATION OF RED CROSS AND RED CRESCENT SOCIETIES. International disaster response laws, rules and principles (IDRL). Available at: https://www.ifrc.org/en/what-we-do/ disaster-law/about-disaster-law/international-disasterresponse-laws-rules-and-principles/. Accessed: 07 Mar. 2021.

INTERNATIONAL FEDERATION OF RED CROSS AND RED CRESCENT SOCIETIES. Law and legal issues in international disaster response: a desk study. Geneva: International Federation of Red Cross and Red Crescent Societies, 2007. Available at: https:/ /www.ifrc. org/PageFiles/125712/113600-idrl-deskstudy-en.pdf. Accessed: 07 Mar. 2021.

KAPP, Klaus William. The social costs of business enterprise. Nottingham: Spokesman, 1978.
KIM, Richard Pae; EISAQUI, Daniel Dela Coleta. "Máximo existencial possível" no sopesamento entre o direito fundamental à educação superior e o interesse público ao equilíbrio fiscal. In: COSTA, Daniel Castro Gomes da; FONSECA, Reynaldo Soares da; BANHOS, Sérgio Silveira; CARVALHO NETO, Tarcísio Vieira de (coord.). Democracia, justiça e cidadania: desafios e perspectivas-homenagem ao Ministro Luís Roberto Barroso. Tomo II: Pensando as instituições, a justiça e o Direito. Belo Horizonte: Fórum, 2020.

KPMG. The KPMG Green Tax Index: an exploration of green tax incentives and penalties. 2017. Available at: https://assets.kpmg/content/dam/kpmg/tw/ pdf/2017/09/655445_NSS_2017Green_TaxIndex_ v18web.pdf. Accessed: 16 Mar. 2021.

KREIBIHEL, Silvia; PATEL, Shilpa. Delivering the green economy through financial policy. Inquiry into the design of a sustainable financial system: policy innovations for a green economy. Frankfurt School of Finance \& Management-UNEP Collaborating Centre for Climate \& Sustainable Energy Finance, 2014. Available at: http://unepinquiry.org/wp-content/ uploads/2014/05/141017_UNEP-Inquiry-GreenEconomy-through-Financial-Policy-3.pdf. Accessed: 11 Mar. 2021.

LAFER, Celso. Da estrutura à função: o olhar de Bobbio sobre a função promocional do direito. In: LAFER, Celso. Norberto Bobbio: trajetória e obra. São Paulo: Perspectiva, 2013.

LATOUCHE, Serge. D'autres mondes sont possibles, pas une autre mondialisation. Revue du Mauss, v. 2, n. 20, 2002. Available at: https://www.cairn.info/load_pdf. php?ID_ARTICLE=RDM_020_0077\&download=1. Accessed: 18 Mar. 2021.

LEFF, Enrique. Decrecimiento o desconstrucción de la economia: hacia um mundo sustentable. Revista de la Universidad Bolivariana, v. 7, n. 21, 2008.

LEFF, Enrique. Sustentabilidad y racionalidad ambiental: hacia 'otro' programa de sociología ambiental. Revista mexicana de sociología, v. 73, n. 1, 2011.

LEVASSEUR, Lionel. L'écologie, nouveau régulateur du capitalisme? Quaderni, n. 17, p. 79-89, 1992. Available at: https://www.persee.fr/docAsPDF/quad_09871381_1992_num_17_1_944.pdf. Accessed: 11 Mar. 2021. 
LÖWY, Michael. Crise ecologique, capitalisme, altermondialisme. Un point de vue eco-socialiste. Novos cadernos NAEA, v. 11, n. 2, p. 5-14, 2008. Available at: https:/ / periodicos.ufpa.br/index.php/ncn/article/ download/269/417. Accessed: 11 Mar. 2021.

MACALISTER-SMITH, Peter. International bumanitarian assistance: disaster relief actions in international law and organization. Dordrecht: Martinus Nijhoff Publishers, 1985.

MACHADO, Paulo Affonso Leme. Direito à informação e meio ambiente. 2. ed. São Paulo: Malheiros, 2018.

MANKIW, Nicholas Gregory. Principles of microeconomisc. 5. ed. Mason: South-Western Cengage Learning, 2008.

McADAMS, Richard H. A focal point theory of expressive law. Law and economics working paper series, working paper n. 00-14, 2000.

MEXICO. General Law for Climate Change. Available: https://www.profepa.gob.mx/innovaportal/ file/6583/1/ley_general_de_cambio_climatico.pdf. Accessed: 16 Mar. 2021.

MINAS GERAIS. Law n. 18.030, of January 12, 2009. Available at: https://www.almg.gov.br/consulte/legislacao/completa/completa-nova-min.html?tipo=LEI\& num $=18030 \& a n o=2009$. Accessed: 14 Mar. 2021.

MONEBHURRUN, Nitish. Is investment arbitration an appropriate venue for environmental issues? A Latin American perspective. Revista de Direito Internacional, Brasília, v. 10, n. 1, p. 195-206, 2013. Available: https:// www.publicacoesacademicas.uniceub.br/rdi/article/ view/2070/pdf. Accessed: 09 May. 2021.

MONEBHURRUN, Nitish. Mapping the Duties of Private Companies in International Investment Law. Revista de Direito Internacional, Brasília, v. 14, n. 2, p. 49-71, 2017. Available: https://www.publicacoesacademicas. uniceub.br/rdi/article/view/4860. Accessed: 05 May. 2021.

MONEBHURRUN, Nitish. Novelty in International Investment Law: The Brazilian Agreement on Cooperation and Facilitation of Investments as a Different International Investment Agreement Model. Journal of International Dispute Settlement, v. 8, 2017. Available: https:// www.researchgate.net/publication/290474976_Novelty_in_International_Investment_Law_The_Brazilian_ Agreement_on_Cooperation_and_Facilitation_of_In-
vestments_as_a_Different_International_Investment_ Agreement_Model. Accessed: 08 May. 2021.

NEVES, Vitor. O problema dos custos sociais. In: CENTEMERI, Laura; CALDAS, José Castro (coord.). Valores em conflito: megaprojetos, ambiente e território. Coimbra: Almedina, 2016.

PARIS, Roland. Human security: paradigma shift or hot air? International Security, v. 26, n. 2, p. 87-102, 2001. Available at: http://users.metu.edu.tr/utuba/Paris.pdf. Accessed: 05 Mar. 2021.

PIGOU, Arthur Cecil. The economics of welfare. London: Macmillan, 1920.

POTTIER, Antonin. Le capitalisme est-il compatible avec les limites écologiques? Paris: Veblen Institute for Economic Reforms, 2017. Available at: https://www.vebleninstitute.org/IMG/pdf/texte_veblen.pdf. Accessed: 11 Mar. 2021.

PSCHEIDT, Kristian Rodrigo. Social development and private health care system: three ways for success. Revista de Direito Econômico e Socioambiental, Curitiba, v. 6, n. 2, p. 29-49, jul./dez. 2015. Available at: https://periodicos.pucpr.br/index.php/direitoeconomico/article/ download/5762/5690. Accessed: 13 Mar. 2021.

RABBANI, Roberto Muhákir Rahnemay. Poluição Sonora e proteção ambiental: intervenção estatal atual e possibilidade da tributação ambiental. Revista de Direito Econômico e Socioambiental, Curitiba, v. 7, n. 2, p. 03-21, jul. /dez. 2016. Available at: https://periodicos.pucpr. br/index.php/direitoeconomico/article/download/5789/5720. Accessed: Mar. 13, 2021.

RIBAS, Lídia Maria; PINHEIRO, Hendrick.Taxa de resíduos sólidos como instrumento para promoção do Direito Fundamental ao Meio Ambiente Equilibrado. Revista de Direito Econômico e Socioambiental, Curitiba, v. 10, n. 2, p. 233-260, maio/ago. 2019. Available at: https:// periodicos.pucpr.br/index.php/direitoeconomico/article/download/23915/24220. Accessed: 13 Mar. 2021.

SÃO PAULO. Law n. 10.705, of December 28, 2000. Available at: https://legislacao.fazenda.sp.gov.br/Paginas/ lei10705.aspx. Accessed: 16 Mar. 2021.

SEN, Amartya. Desenvolvimento como liberdade. São Paulo: Companhia das Letras, 2010.

SHERWOOD, Matthew W.; POLLARD, Julia. Responsible investing: an introduction to environmental, social and 
governance investments. London, New York: Routledge, 2019.

SOUTH AFRICA. Act n. 13 of 2020: Disaster management tax relief act, 2020. Available at: https://www.gov. za/sites/default/files/gcis_document/202011/43883gon1188.pdf. Accessed: 16 Mar. 2021.

TERENZI, Gabriel Vieira. Preferências eleitorais como referência ao controle jurisdicional de políticas públicas. In: GOMES, Daniel Machado; SALLES, Denise Mercedes Lopes; RABELLO, Elaine Teixeira; CAVALCANTI, Marcia Teixeira (org.) Teoria e empiria das politicas públicas. Rio de Janeiro: FGB / Pembroke Collins, 2020.

TRENNEPOHL, Terence Dorneles. Incentivos fiscais no direito ambiental para uma matriz energética limpa e o caso do etanol brasileiro. 2. ed. São Paulo: Saraiva, 2011.

TUSHNET, Mark. Notes on some aspects of the taxonomy of "generations" of rights: a dossier on taxonomy of generation of rights. Revista estudos institucionais, v. 2, n. 2, 2016. Available at: https://www.estudosinstitucionais.com/REI/article/download/77/94. Accessed: 27 Feb. 2021.

UNITED NATIONS. Paris Agreement. 2015. Available at: https://unfccc.int/sites/default/files/english_paris_agreement.pdf. Accessed: 07 Mar. 2021.

UNITED NATIONS. Report of the United Nations Conference on Environment and Development. 1992. Available at: https://www.un.org/en/development/ desa/population/migration/generalassembly/docs/ globalcompact/A_CONF.151_26_Vol.I_Declaration. pdf. Accessed: 06 Mar. 2021.

UNITED NATIONS. Report of the World Conference on Disaster Reduction. 2005. Available at: https://undocs. org/en/A/CONF.206/6. Accessed: 07 Mar. 2021.

UNITED NATIONS. Treaty series: treaties and international agreements registered or filed and recorded with the Secretariat of the United Nations, vol. 1102. New York: United Nations, 1991. Available at: https:// treaties.un.org/doc/Publication/UNTS/Volume\%20 1102/v1102.pdf. Accessed: 06 Mar. 2021.

UNITED NATIONS. Treaty series: treaties and international agreements registered or filed and recorded with the Secretariat of the United Nations, vol. 1457. New York: United Nations, 1997. Available at: https:// treaties.un.org/doc/Publication/UNTS/Volume\%20 1457/v1457.pdf. Accessed: 07 Mar. 2021.
UNITED NATIONS. Treaty series: treaties and international agreements registered or filed and recorded with the Secretariat of the United Nations, vol. 2172. New York: United Nations, 2004. Available at: https://treaties.un.org/doc/publication/unts/volume\%202172/ v2172.pdf. Accessed: 07 Mar. 2021.

UNITED NATIONS. Treaty series: treaties and international agreements registered or filed and recorded with the Secretariat of the United Nations, vol. 2296. New York: United Nations, 2006. Available at: https:/ / treaties.un.org/doc/Publication/UNTS/Volume $\% 20$ 2296/v2296.pdf. Accessed: 07 Mar. 2021.

VELTMEYER, Henry. Civil Society and Local Development. Interações, v. 9, n. 2, p. 229-243, 2008. Available at: http://www.scielo.br/scielo.php?script=sci_ arttext\&pid=S1518-70122008000200010\&lng=en\&nr $\mathrm{m}=$ iso.Accessed: 11 Mar. 2021.

VIEIRA, Rosa Maria. O fim da historia: de Hegel a Fukuyama. Revista de Administração de Empresas, v. 33, n. 3, 1993. Available at: https://www.fgv.br/rae/artigos/ revista-rae-vol-33-num-3-ano-1993-nid-47481/. Accessed: 11 Mar. 2021.

ŽIŽEK, Slavoj. In defense of lost causes. London, New York: Verso, 2008. 
Para publicar na Revista de Direito Internacional, acesse o endereço eletrônico www.rdi.uniceub.br ou www.brazilianjournal.org.

Observe as normas de publicação, para facilitar e agilizar o trabalho de edição. 